\title{
Empirical Investigation of the Relationship between Continuing Overreaction and Stock Returns
}

\author{
Somyung Kim", Ph.D. Candidate, Pusan National University \\ Kiyool Ohk, Professor, Pusan National University
}

\begin{abstract}
$\langle$ Abstract $\rangle$
This study investigates the relationship between continuing overreaction (CO) and future stock returns in the Korean stock market. Investors' overconfidence and biased self-attribution explain the stock market's underreaction and overreaction. We represent a proxy for the CO with monthly trading volumes and monthly returns and validate the predictive power of $\mathrm{CO}$ on stock returns in the Korean stock market. Specifically, based on CO, we form 10 equal-weighted portfolios at the end of each month and the CO strategy of buying the portfolio with the highest $\mathrm{CO}$ and selling the portfolio with the lowest $\mathrm{CO}$ is profitable. We also develop existing studies to reaffirm the impact of continuing overreaction on stock returns, with firm characteristic factors, momentum phenomena, return consistency, information discreteness, and unrealized capital gains as control variables. Furthermore, we introduce residual CO using residual returns to compare the profitability of residual momentum with residual CO strategies. The effects of $\mathrm{CO}$ on market states and market dynamics are also analyzed. Consequently, it is confirmed that a zero-cost investment with $\mathrm{CO}$ has statistically significant positive returns, which predicts future returns better than past returns.
\end{abstract}

Keywords: Continuing Overreaction; Momentum; Return Predictability; Overconfidence; Behavioral Finance

JEL Classification: G10, G11

* Corresponding Author. Address: Pusan National University, 2, Busandaehak-ro 63 beon-gil, Geumjeong-gu, Busan, Korea 46241; E-mail: somyung.kim@pusan.ac.kr; Tel: +82-51-510-7663; Fax: +82-51-581-3144.

Received: November 12, 2020; Revised: January 18, 2021; Accepted: February 5, 2021 


\title{
계속적 과잉반응과 주식수익률의 관계에 관한 연구
}

\author{
김 소 명 (부산대학교 박사과정)* \\ 옥 기 율 (부산대학교 교수)
}

\begin{abstract}
본 연구는 국내 주식시장에서 계속적 과잉반응과 미래 주식수익률의 관계를 조사한다. 투자자의 과신과 편향된 자기귀인이 주식시장의 과소반응과 과잉반응을 설명한다. 우리는 월별거래대금과 월별수익률로 계속적 과잉반응의 대용치를 나타내고 국내 주식시장에서 주식수익률에 대한 계속적 과잉반응의 예측력을 검증한다. 구체적으로, 계속적 과잉반응 $(\mathrm{CO})$ 을 기반으로 매월 말 10 개의 동일가중 포트폴리오를 구성하여 $\mathrm{CO}$ 가 가장 높은 포트폴리오를 매수하고 $\mathrm{CO}$ 가 가장 낮은 포트폴리오를 매도하는 $\mathrm{CO}$ 전략이 수익성을 가짐을 보인다. 기존의 연구를 발전시켜 기업특성 요인, 모멘텀 현상, 수익률 지속성, 정보의 불연속성과 미실현 자본이익을 통제변수로 하여 주식수익률에 대한 계속적 과잉반응의 영향을 재확인한다. 또한, 잔여수익률을 이용한 잔여 계속적 과잉반응을 도입하여 잔여모멘텀과 잔여 계속적 과잉반응 전략의 수익성을 비교한다. 더 나아가, 시장상태와 시장동태에 따른 계속적 과잉반응의 영향을 분석한다. 결과적으로, 계속적 과잉반응에 따른 무비용 포트폴리오는 통계적으로 유의한 양의 수익률을 가지며 이는 과거수익률 보다 미래수익률을 더 잘 예측한다는 것을 확인한다.
\end{abstract}

핵심 단어 : 계속적 과잉반응, 모멘텀, 주식수익률 예측가능성, 과신, 행동재무학

JEL 분류기호: G10, G11

* 연락담당 저자. 주소: 부산광역시 금정구 부산대학로63번길 2 부산대학교 경영대학, 46241 ; E-mail: somyung.kim@pusan.ac.kr; Tel: 051-510-7663; Fax: 051-581-3144. 


\section{1. 서론}

행동재무학(behavioral finance)이 발전함에 따라 투자자의 과신(overconfidence)이 주식 시장과 기업의 의사결정에 대한 넓은 범위의 현상을 설명할 수 있다는 연구가 등장하기 시작했다. Chen et al.(2007)은 신흥시장에서 중국 투자자들이 디스포지션 효과, 과신, 그리고 대표성 편향으로 인해 비합리적인 의사결정을 하고 결과적으로 낮은 투자성과를 가진다고 주장한다. Statman et al.(2006)은 투자자의 과신과 편향된 자기귀인(biased self-attribution)으로 인해 거래량이 증가하는 현상을 확인하고, 거래량회전율과 수익률간의 유의한 양의 관계를 발견한다. Daniel et al.(1998)은 투자자의 과신과 편향된 자기귀인이 주식시장의 과소반응(underreaction)과 과잉반응(overreaction)을 설명할 수 있다고 주장한다. Daniel et al.(1998)의 모형에 따르면, 투자자는 스스로의 능력을 과신하여 그들의 사적인 정보(private information)에 대하여 과잉반응한다. 투자자의 과신은 그들의 양의(음의) 사적인 정보에 대한 추가적인 과잉반응을 야기하므로 과거수익률은 미래수익률을 예측하게 된다. 이처럼, 계속적인 과잉반응(continuing overreaction, $\mathrm{CO}$ )은 투자자가 자신의 능력을 과신하여 사적인 정보에 과잉반응하고 차후 발생되는 공적인 신호(public signals)가 그들의 과신을 더욱 증가시켜, 결과적으로 그들의 사적인 정보에 대한 더 높은 과잉반응을 야기하는 것을 의미한다. 사적인 정보에 대한 투자자의 계속적 과잉반응이 단기적으로 모멘텀 현상을 발생시킨다면, 이는 과거수익률보다 미래수익률을 잘 예측할 수 있을 것이다. Byun et al.(2016)은 계속적 과잉반응에 대한 측정치를 구성하여 Daniel et al.(1998)에 대한 실증적 증거를 제공한다. 본 연구에서는 계속적 과잉반응의 측정치를 이용하여 국내 주식시장에서 계속적 과잉반응이 과거수익률보다 미래수익률을 더 잘 예측하고, 계속적 과잉반응으로 인해 모멘텀 효과가 약화됨을 보인다.

본 연구에서는 계속적 과잉반응을 나타내는 $\mathrm{CO}$ 변수를 국내 주식시장에 도입하여 미래수익률을 예측하는지 여부를 검토한다. $\mathrm{CO}$ 변수는 월별거래대금과 부호화된 동시간대 수익률로 구성하며 과거 12 개월 동안 가중치가 적용된 월별 부호화된 거래량(signed volume)의 합계로 도출된다. Benos(1998)와 Odean(1998)은 투자자의 과신이 거래량을 증가시키는 현상을 제시하여 거래량이 투자자의 과신과 과잉반응의 대용치로 사용될 수 있다고 주장한다. 우리는 $\mathrm{CO}$ 변수가 미래 수익률에 대한 예측력을 가지는지 평가한다. 먼저, $\mathrm{CO}$ 변수로 10 분위수 포트폴리오를 구성하고, $\mathrm{CO}$ 가 가장 높은 포트폴리오를 매입하고 가장 낮은 포트폴리오를 매도하는 $\mathrm{CO}$ 전략을 구성한다. 만약, $\mathrm{CO}$ 변수가 미래 수익률에 유의한 예측력을 가진다면, 6 개월에서 12 개월간의 보유기간동안 유의한 양의 수익률을 가질 것이다.

우리는 기존의 연구에서 $\mathrm{CO}$ 와 모멘텀과의 관계에 집중한 것을 발전시켜, 통제변수의 영향을 확인한다. 통제변수를 포함하는 것은 계속적 과잉반응이 주식수익률에 영향을 미친다는 타당성을 높인다. 선행연구에 따르면 계속적 과잉반응은 모멘텀현상에 핵심요인으로 작용한다. 먼저, 우리는 기준조정 수익률을 통해 CO전략과 모멘텀전략의 수익성을 비교분석한다. 국내 주식시장 에서 계속적 과잉반응의 모멘텀 조정수익률은 $\mathrm{CO}$ 와 유의한 양의 관계에 있다는 것을 확인하는 반면, 모멘텀 수익률은 계속적 과잉반응에 의해 부분적으로 통제됨을 확인한다. 둘째, $\mathrm{CO}$ 가 
Empirical Investigation of the Relationship between Continuing Overreaction and Stock Returns

기업특성 요인에 의해 통제 되는지 여부를 확인하기 위해 다변량 분석을 진행한다. 기업특성 요인은 기존의 연구들에 의해 주식수익률에 유의한 영향을 준다고 나타난 시장베타(BETA), 기업규모(SIZE), 장부가치 대 시장가치(BEME), 과거수익률(PRET), 단기수익률반전(REV), 유동성(ILLIQ), 고유변동성(IVOL)이며, 본 연구에서 사용하는 $\mathrm{CO}$ 는 거래량을 기반으로 도출되기 때문에 거래량회전율(TURN)을 추가적으로 고려한다. 기업특성 요인들을 통제한 경우에 CO 전략의 수익성은 여전히 유의한 양의 값이며, 이는 $\mathrm{CO}$ 전략이 주식수익률에 가지는 예측력은 기업특성 요인에 의존한 것이 아님을 나타낸다. 셋째, Grinblatt and Moskowitz(2004)와 Da et al.(2014)은 수익률 지속성(return consistency)과 정보의 불연속성(information discreteness)이 과거수익률과 주식수익률간의 관계에 영향을 미치는지 확인한다. Grinblatt and Moskowitz(2004)는 과거수익률이 양의 값으로 지속된다면 기대수익률은 과거수익률의 지속성에 유의한 영향을 받는다고 나타낸다. Da et al.(2014)은 포트폴리오 구성기간동안 정보의 흐름이 연속적인지 여부를 확인하는 측정치로 정보의 불연속성(information discreteness, ID)을 제시하고, 연속적인 정보는 더 강한 수익률의 지속을 유도한다고 나타낸다. 따라서 동일한 방향의 수익률 시계열을 가진 주식은 극단적인 $\mathrm{CO}$ 포트폴리오에 포함될 경향이 있고, 이러한 주식은 높은 수준의 수익률 지속성과 낮은 수준의 정보 불연속성을 가질 가능성이 있다. 우리는 포트폴리오 분석을 통하여 $\mathrm{CO}$ 전략이 정보의 불연속성의 효과에 기인하는지 여부를 확인한다. 더 나아가, Fama and MacBeth(1973)의 횡단면 회귀분석을 이용하여 기업특성 요인과 행태적 요인을 동시에 통제한 후에도 $\mathrm{CO}$ 전략이 횡단면적으로 주식수익률에 유의한 예측력을 가지는지 확인 한다. 넷째, Grinblatt and Han(2005)에 따르면 미실현 자본이익의 대용변수가 모멘텀전략의 수익성을 창출하는 핵심변수이므로 미실현 자본이익 변수를 통제한 경우에는 과거수익률이 횡단면적으로 수익률을 예측하지 못한다. 우리는 모멘텀전략의 핵심변수로 나타난 미실현 자본이익과 계속적 과잉반응의 동시간대 영향을 확인한다. 다변량 포트폴리오 분석을 통하여 두 변수 중 주식수익률에 대해 더 강한 예측력을 가지는 변수를 확인하고, 국내 주식시장에서 나타나는 비대칭적 미실현 자본이익을 고려하여 CO전략의 수익성을 확인한다. 다섯째, Blitz et al.(2011)에서 제시한 잔여모멘텀(residual momentum)에 따라 잔여수익률을 이용한 잔여 계속적 과잉반응을 도출한다. 잔여모멘텀 전략이 기존의 모멘텀 전략보다 2 배가량 높은 수익률과 지속성을 가진다는 선행연구와는 달리, 잔여 계속적 과잉반응 전략은 기존의 수익률 계속적 과잉반응에 비하여 낮은 수익률을 가진다. 그럼에도 불구하고, 잔여 계속적 과잉반응은 주식 수익률에 대해 유의한 양의 예측력을 가지며 잔여모멘텀에 의해 통제되지 않는다.

포트폴리오를 구성하는 과거 기간과 시장상태, 시장동태에 따른 계속적 과잉반응을 확인하여 $\mathrm{CO}$ 전략의 수익성을 재점검한다. 먼저, 포트폴리오 구성기간을 과거 6개월, 9 개월, 18 개월과 24 개월로 변경하여도 주식수익률에 대한 계속적 과잉반응의 양의 영향은 지속되는 것을 확인한다. 또한, 단기 모멘텀 수익률이 시장상태와 시장동태에 따라 결정된다는 Cooper et al.(2004)과 Asem and Tian(2010)의 연구를 따라 시장상태와 시장동태에 따른 계속적 과잉반응과 주식 수익률 간의 관계를 확인한다. 시장상태를 기준으로 분석한 결과에 따르면 상승시장과 하락시장 에서 $\mathrm{CO}$ 전략은 모두 유의한 양의 수익률을 가진다. 상승시장과 하락시장 결과간의 차이를 
한국증권학회지 제 50 권 1호 (2021)

통해 두 시장의 수익률 차이가 없다는 것을 확인하여 $\mathrm{CO}$ 전략은 시장상태에 큰 영향을 받지 않음을 나타낸다. 더 나아가, 시장동태에 따라 $\mathrm{CO}$ 전략을 분석한다. 과거시장이 상승시장 이라면 상대적으로 높은 수익률을 가지며, 동시간대 시장이 상승시장일 때 그렇지 않은 경우에 비하여 더 높은 수익률을 가진다. 종합하면 과거시장이 상승시장이며 동시간대 시장도 상승시장 으로 유지될 경우에 $\mathrm{CO}$ 전략의 수익성은 가장 높고, 주식수익률에 대한 계속적 과잉반응의 예측력이 가장 강하다.

본 연구는 국내 주식시장에서 투자자의 계속적 과잉반응이 주식수익률이 미치는 현상을 조사한다. 월별거래대금과 월별수익률을 기반으로 도출된 계속적 과잉반응의 측정치는 주식 수익률간의 유의한 양의 관계에 있다. 다시 말해, 국내 주식시장에서 투자자는 그들의 사적인 정보에 대해 과잉반응한다. 더 나아가, 다양한 통제변수를 도입하여 주식수익률에 대한 계속적 과잉반응의 예측력을 재점검한다. 기업특성 요인과 행태적 요인을 고려한 후에도 계속적 과잉반응 전략의 수익성이 유지되므로 국내 주식시장에서 거래량을 이용한 투자전략이 수익성을 가진다는 사실을 확인한다. 본 연구는 투자자의 계속적 과잉반응과 주식수익률에 유의한 관계를 확인하여 관련분야의 시사점을 제시한다. 또한, 행동재무학 관점에서 투자자의 비합리적인 행동을 확인 한다는 점에서 기여를 가진다.

본 연구는 다음과 같이 구성된다. 제 2장은 선행연구를 나타내고, 제 3장에서는 계속적 과잉 반응과 주요 변수, 자료 및 방법론에 대해 설명한다. 제 4장에서는 계속적 과잉반응과 주식수익률의 관계를 확인한다. 모멘텀, 기업특성 요인, 수익률 지속성, 정보의 불연속성, 그리고 미실현 자본이익을 통제한 결과를 나타내고 그 내용을 해석한다. 추가적으로 잔여 계속적 과잉반응과 주식수익률간의 관계를 확인한다. 제 5 장에서는 강건성 검정을 나타내고, 제 6 장에서는 결론을 제시한다.

\section{2. 선행연구}

Daniel et al.(1998)에 따르면 투자자의 과신과 편향된 자기귀인이 주식시장의 과소반응과 과잉반응을 설명한다. 투자자는 스스로의 능력을 과신하여 그들의 사적인 정보에 대하여 과잉 반응한다. 차후에 발생하는 공적 신호(public signal)는 그들의 사적인 정보에 대한 과잉반응을 촉진시킨다. 이와 같은 과잉반응은 편향된 자기귀인으로 이어져 추가적인 과신을 야기한다. 따라서 높은(낮은) 과거수익률은 투자자가 그들의 양의(음의) 사적인 정보에 더욱 과신하게 하며 투자자의 과신은 양의(음의) 사적인 정보에 대한 추가적인 과잉반응을 야기한다. 사적인 정보에 대한 투자자의 계속적 과잉반응(continuing overreaction: $\mathrm{CO}$ )은 단기적으로 모멘텀 현상을 야기하며 과거수익률은 미래 수익률을 예측하게 된다. Daniel et al.(1998)의 결과와 같이 계속적 과잉반응이 모멘텀 현상을 유발한다면, 이는 과거수익률 보다 미래수익률을 잘 예측할 것이다.

이와 유사하게 많은 실증연구들은 투자자의 과신과 거래량의 관계에 대한 증거를 제시한다. Benos(1998)에 따르면 일부 위험 중립적 투자자들이 그들의 사적인 정보를 과대평가하여 
Empirical Investigation of the Relationship between Continuing Overreaction and Stock Returns

과신하는 현상이 발생하고, 결과적으로 과신이 거래량을 증가시킨다. Gervais and Odean (2001)은 거래자가 그들의 능력에 대해 과신한다는 사실을 확인하고 투자자의 과신에 따른 거래량과 기대이익, 가격변동성, 기대가격의 변화패턴을 분석한다. Glaser and Weber(2009)에 따르면 과거 포트폴리오 수익률은 개인 투자자의 거래활동(거래량, 포트폴리오 회전율 등)에 영향을 미치며 투자자의 과신에 의해 높은 수준의 거래량이 발생한다. 위의 실증 결과에 따르면 거래량은 투자자의 과신과 과잉반응을 나타내는 대용치가 된다.

최근의 많은 연구는 투자자의 과신이 주식시장에 미치는 영향을 나타내며 기존 연구결과를 지지하는 실증적 증거를 제시한다. Luo et al.(2021)은 정보에 대해 과신하는 투자자는 주식시장에 과잉 유동성을 공급을 유도하며, 이는 모멘텀 현상과 이어진다고 주장한다. Chuang and Lee(2006)에 따르면 투자자는 사적인 정보에 과잉반응하고 공적인 정보에 과소반응한다. 따라서 투자자의 과신은 투자자를 더욱 공격적이게 만든다. Adebambo and Yan(2016)은 모멘텀 효과를 설명하는데 있어 투자자의 과신과 편향된 자기귀인의 역할을 검토한다. 과신이 높은 펀드 매니저가 그렇지 못한 펀드매니저보다 더 큰 모멘텀 이익과 더 강한 수익률 반전현상을 가지는 것을 확인하여 Daniel et al.(1998)을 지지한다. Cooper et al.(2004)에 따르면 모멘텀 전략의 수익성은 시장의 상태에 따라 변화하고 Daniel et al.(1998)의 결과와 동일하게 상승시장(up market)에서 모멘텀 전략의 수익성이 높다. Chui et al.(2010)은 투자자의 과신과 편향된 자기귀인에 관련된 개인주의 지수를 측정하여 문화적 차이가 모멘텀 전략의 수익률에 미치는 영향을 조사한다. Hou et al.(2009)에 따르면 상승시장에서 거래량이 많은 주식은 모멘텀 이익을 취한다. Byun et al.(2016)은 Daniel et al.(1998)을 바탕으로 계속적 과잉반응을 나타내는 측정치를 정의한다. 더 나아가, 계속적 과잉반응과 주식수익률의 양의 관계를 확인한다.

Byun et al.(2016)은 미국 주식시장으로 표본으로 계속적 과잉반응에 대한 측정치를 도출하여 Daniel et al.(1998)에 대한 실증적 증거를 제공한다. 계속적 과잉반응(continuing overreaction)을 나타내는 $\mathrm{CO}$ 변수는 동시간대 주식수익률과 월별거래대금으로 구성된다. 거래대금은 가중치가 부여된 부호화된 거래량을 사용한다. Byun et al.(2016)에 따르면 CO는 과거수익률보다 미래수익률에 대한 예측력이 높고, $\mathrm{CO}$ 전략의 수익성은 모멘텀 전략의 수익률을 조정한 후에도 유지된다. $\mathrm{CO}$ 가 가장 높은 주식을 매입하고 $\mathrm{CO}$ 가 가장 낮은 주식을 매도하는 $\mathrm{CO}$ 전략은 유의한 양의 수익률을 가지며, $\mathrm{CO}$ 전략의 수익률은 포트폴리오 구성이후 12 개월까지 지속된다.

\section{3. 자료 및 방법론}

\section{1 계속적 과잉반응}

Daniel et al.(1998)에 따르면 투자자는 사적인 정보(private information)에 대해 과신(overconfidence)하는 경향이 있다. 또한, 투자자의 편향된 자기귀인(biased self-attribution)은 주식 시장에서 발생하는 과소반응(under-reaction)과 과대반응(over-reaction)을 설명한다. 계속적 과잉반응은 투자자가 그들의 사적인 정보에 대하여 과신할 때 발생한다. 높은(낮은) 과거수익률은 양(음)의 사적인 정보에 대한 투자자의 양(음)의 계속적 과잉반응을 야기한다. Daniel et 
한국증권학회지 제 50 권 1호 (2021)

al.(1998)에 따르면 과거수익률은 미래수익률에 대한 예측력을 가진다. 따라서 과거수익률을 기반으로 정의한 계속적 과잉반응은 미래수익률을 예측한다. 즉, 계속적 과잉반응은 미래수익률에 대한 직접적인 측정치이며 투자자의 계속적인 과잉반응이 모멘텀 현상을 야기한다. Byun et al.(2016)은 Daniel et al.(1998)에 따라 계속적 과잉반응을 나타내는 실증적인 측정치를 제시한다. 더 나아가, 투자자의 과신과 편향된 자기귀인으로 인한 계속적 과잉반응이 주식수익률에 대한 예측성을 가지는지 여부를 확인한다. 계속적 과잉반응의 측정치는 다음과 같이 구성된다.

첫째, 월별거래량을 투자자의 과신 또는 과잉반응의 대용치로 사용한다. Benos(1998)에 따르면 투자자는 그들의 사적인 정보에 대하여 더 많은 가중치를 부여한다. 따라서 투자자의 과신은 더욱 공격적인 거래를 야기한다. Benos(1998)와 Odean(1998)의 연구는 과신이 거래량을 증가시키므로 높은 거래량이 과신의 정도라고 나타낸다. Statman et al.(2006)은 벡터자기 회귀모형과 충격반응함수를 이용하여 시장의 전반적인 거래량이 투자자의 과신과 디스포지션 효과를 설명할 수 있다고 제시한다. Grinblatt and Keloharju(2009)는 핀란드 주식거래 데이터를 이용하여 감각 추구(sensation seeking)와 과신이 투자자의 주식거래에 미치는 영향을 확인한다. 특히, 재산, 소득, 나이, 주식 보유 수 등을 포함한 다수의 변수를 통제하여 거래빈도가 높은 투자자일수록 과신하는 경향이 높음을 보인다. 위의 연구들은 투자자의 과신과 거래량간의 유의한 양의 관계를 제시하고, 거래량이 투자자의 과신 또는 과잉반응을 나타내는 대용치로 사용될 수 있음을 뒷받침한다.

둘째, 동시간대 월별수익률과 월별거래대금을 통해 부호화된 거래량(signed volume)을 구성하여 투자자의 과잉반응의 방향을 나타낸다. Byun et al.(2016)에 따르면 양의 수익률을 동반하는 높은 수준의 거래량은 양의 사적인 정보에 대한 투자자의 과신을, 음의 수익률을 동반하는 높은 수준의 거래량이 음의 사적인 정보에 대한 투자자의 과신을 의미한다.

$t$ 월의 $i$ 번째 주식의 부호화된 거래량은 다음과 같다.

$$
S V_{i, t}= \begin{cases}V O L_{i, t} & \text { if } r_{i, t}>0, \\ 0 & \text { if } r_{i, t}=0, \\ -V O L_{i, t} & \text { if } r_{i, t}<0,\end{cases}
$$

$r_{i, t}$ 는 $t$ 월의 $i$ 번째 주식수익률이다. $V O L_{i, t}$ 는 $t$ 월의 $i$ 번째 주식의 월별거래대금으로 각 달의 일별거래량에 종가를 곱한 값의 합으로 정의한다. 계속적 과잉반응 $(\mathrm{CO})$ 은 식 (2)에 따라 도출된다. 먼저, 최근의 부호화된 거래량에 더 높은 가중치를 부여하고 부호화된 거래량의 합을 구한다. 다음으로, 동일한 기간의 평균 거래량으로 가중치가 부여된 부호화된 거래량을 정규화한다. 이는 시간에 따라 증가 또는 하락하는 투자자의 과신을 확인한다.

$$
C O_{i, t}=\frac{\sum_{j=1}^{J}\left(w_{j} \times S V_{i, t-j}\right)}{\operatorname{mean}\left(V O L_{i, t-J}, \ldots, V O L_{i, t-1}\right)}
$$

$S V_{i, t}$ 는 식 (1)에 의해 도출된 $t$ 월의 $i$ 번째 주식의 부호화된 거래량이고, $J$ 는 포트폴리오 
Empirical Investigation of the Relationship between Continuing Overreaction and Stock Returns

구성기간이다. 본 연구에서는 포트폴리오 구성기간을 1 년 $(J=12)$ 으로 설정한다. 도출기간을 변경한 결과는 제 5 장 제 1 절에 나타낸다. $w_{i}$ 는 $t-j$ 월에 부여하는 가중치로 $J-j+1$ 의 값이다 $\left(w_{J}=1, w_{J-1}=2, \ldots, w_{1}=J\right)$. 본 연구에서는 $C O_{i, t}$ 를 투자자의 계속적 과잉반응을 나타내는 측정치로 사용한다.

Daniel et al.(1998)의 연구는 편향된 자기귀인이 중기(intermediate-term)수익률을 예측하는 핵심요소라고 나타낸다. 따라서 편향된 자기귀인은 과신의 증가추세를 나타내는 계속적 과잉반응으로 이어진다. 포트폴리오 구성기간동안 평균 거래량을 유지한다면, 최근 달의 거래량에 가중치가 높을수록 거래량의 합은 더욱 높아진다. Lee and Swaminathan(2000)에 따르면 과거거래량은 가격모멘텀의 규모와 지속성을 예측하며 중기수익률의 과소반응과 장기수익률의 과잉반응효과를 조정하는데 도움을 준다. 따라서 부호화된 거래량을 합하고 동일기간의 평균거래량으로 정규화한 값은 투자자 과신의 추세를 나타낸다.

\section{2 주요 변수}

본 연구에서는 $\mathrm{CO}$ 와 주식수익률 간의 횡단면적 관계를 조사하기 위해 기업특성 요인의 영향을 고려한다. 기업특성 요인의 정의는 다음과 같다.

기업규모(SIZE)와 장부가치 대 시장가치(BEME)는 Fama and French(1992, 1993)에 따른 시장가치의 자연로그를 취한 값과 회계연도 장부가치 대 시장가치 비율(book-to-market ratio)이다. 상대적으로 레버리지가 높은 기업(금융업, 은행업, 보험업 등)은 표본에서 제외한다. 시장베타(BETA)는 식 (3)에 따라 $t$ 월의 초과수익률과 시장 초과수익률을 사용하여 계산한다. 매 월 일별 수익률 관측치의 개수가 12 개 미만인 주식은 제외한다.

$$
R_{i, d}-r_{f, d}=\alpha_{i}+\beta_{i}\left(R_{m, d}-r_{f, d}\right)+\epsilon_{i, d}
$$

$R_{i, d}$ 은 $d$ 일의 $i$ 번째 주식수익률이고, $R_{m, d}$ 은 $d$ 일의 시장수익률이다. $r_{f, d}$ 은 $d$ 일의 무위험 수익률이다. 우리는 매월 일별 수익률로 식 (3)을 이용하여 각 주식의 베타를 구한다. $\hat{\beta}_{i}$ 는 $t$ 월 $i$ 번째 주식의 시장베타이다.

과거수익률(PRET)은 $t-12$ 월부터 $t-2$ 월의 누적수익률이다. 단기수익률반전(REV)은 Jegadeesh(1990)과 Lehmann(1990)에 따른 단기수익률 반전(reversal)이다. 각 주식에 대하여 $t$ 월의 REV는 과거 1 개월 전 수익률로 정의한다. 유동성(ILLIQ)은 Amihud(2002)에 따른 유동성 측정치이며 식 (4)와 같다.

$$
\operatorname{ILLIQ} Q_{i, t}=\frac{1}{D_{i}} \times \frac{\left|R_{i, d}\right|}{\operatorname{VOLD} D_{i, d}}
$$

$R_{i, d}$ 은 $d$ 번째 거래일의 주식수익률이고, $D_{i}$ 는 $t$ 시점에서 $i$ 번째 주식의 거래량이 0 이 아닌 거래일 수를, $V O L D_{i, d}$ 는 $d$ 번째 거래일의 거래대금을 의미한다.

고유변동성(IVOL)은 Bali et al.(2011)에 따른 고유변동성이다. $\epsilon_{i, d}$ 는 식 (3)을 통해 도출되며 월별 IVOL은 $\epsilon_{i, d}$ 에 표준편차를 취한 값으로 식 (5)와 같다. 
한국증권학회지 제 50 권 1 호 (2021)

$$
I V O L_{i, t}=\sqrt{\operatorname{var}\left(\epsilon_{i, d}\right)}
$$

거래량회전율(TURN)은 $t-12$ 월부터 $t-1$ 월의 평균 월별거래량회전율이다.

\section{3 자료}

본 연구는 2000년 1월부터 2020년 6월까지 국내 유가증권시장과 코스닥 시장에 상장된 주식을 표본으로 한다. 자료의 정확성이 떨어지는 것을 방지하기 위하여 종가가 500 원 이하인 주식은 표본에서 제외한다. 상장 폐지된 주식의 경우 상장 폐지 전 6개월의 주가자료와 주식데이터가 12 개월 이하인 기업은 표본에서 제외한다. 본 연구에서는 Fama and French(1993)의 3요인모형에

\section{〈표 1〉기술통계량}

이 표는 2000년 1 월부터 2020년 6월까지 유가증권시장과 코스닥시장에 상장된 기업들의 월별 자료에 대한 기술통계량이다. 패널 $\mathrm{A}$ 는 계속적 과잉반응에 대한 측정치인 $\mathrm{CO}$ 의 평균, 중앙값, 표준편차, $1 \mathrm{st}$, 25 th, 50th, 75th, 99th 분위수의 시계열 평균값을 나타낸다. 패널 $\mathrm{B}$ 는 $\mathrm{CO}$ 를 기준으로 10 분위수 포트폴리오를 구성한 후, 각 포트폴리오에 속하는 변수들의 시계열 평균을 나타낸다. 패널 $\mathrm{C}$ 는 변수들의 횡단면적 상관계수의 시계열 평균을 나타낸다.

\begin{tabular}{|c|c|c|c|c|c|c|c|c|c|}
\hline \multicolumn{10}{|c|}{ 패널 A: CO 요약통계량 } \\
\hline & Mean & Median & Std.dev & \multicolumn{2}{|c|}{ 1st } & 25th & 50th & 75th & 99th \\
\hline $\mathrm{CO}$ & 11.394 & 11.146 & 9.632 & $-12.7 ?$ & & 6.155 & 11.146 & 15.753 & 35.981 \\
\hline \multicolumn{10}{|c|}{ 패널 B: CO 10분위수 포트폴리오의 요약통계량 } \\
\hline & SIZE & BEME & BETA & PRE & & REV & ILLIQ & IVOL & TURN \\
\hline \multirow{9}{*}{ Low } & 24.927 & 1.347 & 0.725 & -0.1 & & -0.059 & 6.427 & 0.030 & 0.430 \\
\hline & 25.066 & 1.335 & 0.735 & -0.1 & & -0.033 & 4.839 & 0.028 & 0.412 \\
\hline & 25.105 & 1.335 & 0.737 & -0.0 & & -0.021 & 4.281 & 0.027 & 0.414 \\
\hline & 25.104 & 1.338 & 0.745 & -0.0 & & -0.012 & 3.234 & 0.027 & 0.419 \\
\hline & 25.133 & 1.355 & 0.754 & 0.0 & & -0.002 & 4.169 & 0.027 & 0.408 \\
\hline & 25.142 & 1.397 & 0.752 & 0.1 & & 0.008 & 2.114 & 0.027 & 0.399 \\
\hline & 25.160 & 1.431 & 0.747 & 0.18 & & 0.018 & 2.920 & 0.027 & 0.399 \\
\hline & 25.194 & 1.466 & 0.769 & 0.26 & & 0.032 & 1.976 & 0.028 & 0.392 \\
\hline & 25.237 & 1.501 & 0.786 & 0.37 & & 0.058 & 1.440 & 0.029 & 0.397 \\
\hline High 10 & 25.184 & 1.624 & 0.840 & 0.5 & & 0.139 & 0.803 & 0.034 & 0.427 \\
\hline \multicolumn{10}{|c|}{ 패널 C: 횡단면적 상관계수의 시계열 평균 } \\
\hline & $\mathrm{CO}$ & SIZE & BEME & BETA & PRET & REV & ILLIQ & IVOL & TURN \\
\hline $\mathrm{CO}$ & 1.000 & & & & & & & & \\
\hline SIZE & 0.049 & 1.000 & & & & & & & \\
\hline BEME & 0.047 & -0.131 & 1.000 & & & & & & \\
\hline BETA & 0.037 & 0.109 & -0.084 & 1.000 & & & & & \\
\hline PRET & 0.351 & 0.190 & -0.023 & 0.051 & 1.000 & & & & \\
\hline $\mathrm{REV}$ & 0.356 & 0.064 & 0.030 & -0.004 & -0.007 & 1.000 & & & \\
\hline ILLIQ & -0.019 & -0.094 & 0.046 & -0.060 & -0.014 & -0.011 & 1.000 & & \\
\hline IVOL & 0.085 & -0.190 & -0.122 & 0.068 & 0.054 & 0.140 & 0.017 & 1.000 & \\
\hline TURN & 0.017 & -0.181 & -0.189 & 0.123 & 0.114 & -0.017 & -0.065 & 0.304 & 1.000 \\
\hline
\end{tabular}


Empirical Investigation of the Relationship between Continuing Overreaction and Stock Returns

따른 위험조정 수익률을 사용한다. 따라서 상대적으로 레버리지가 높은 기업(금융업, 은행업, 보험업 등)은 표본에서 제외한다. 일별수익률은 한국거래소에서 규정한 가격제한폭에 따라 조정한다. 분석기간 중 상장폐지 기업을 제외할 경우 생존편의(survival bias)가 발생하므로 상장폐지 기업도 분석 대상에 포함한다. 시계열 분석에서 사용된 기간은 246 개월이며, 분석 대상 기업 수는 시계열 평균 1499 개이다. 표본에 사용된 자료는 FnGuide에서 제공받았다. 무위험 수익률은 통화안정채권 364일 만기수익률이고, 시장수익률은 매월 모든 기업에 대한 가치가중수익률이다.

<표 1>은 본 연구에서 사용된 자료에 대한 기술통계량이다. 패널 $\mathrm{A}$ 는 $\mathrm{CO}$ 의 요약통계량이다. 패널 $\mathrm{B}$ 는 매월 $\mathrm{CO}$ 를 기준으로 구성한 10 분위수 포트폴리오에 속한 주식의 변수 값의 시계열 평균이다. 패널 $\mathrm{C}$ 는 변수간의 횡단면적 상관관계의 시계열 평균이다. $\mathrm{CO}$ 의 평균값은 11.394 이며 표준편차는 9.632이다. <표 1>의 패널 $\mathrm{B}$ 에 따르면 $\mathrm{CO}$ 가 높은 주식일수록 기업규모(SIZE), 장부가치 대 시장가치(BEME), 시장베타(BETA), 과거수익률(PRET), 단기수익률반전(REV), 고유변동성(IVOL)이 높은 경향이 있다. 반면, CO가 증가함에 따라 유동성(ILLIQ)은 하락하는 경향이 있으며, 거래량회전율(TURN)의 경우 $\mathrm{CO}$ 와 눈에 띄는 관계가 나타나지 않는다. <표 $1>$ 의 패널 $\mathrm{C}$ 에 의하면 패널 $\mathrm{B}$ 와 유사하게 기업규모(SIZE), 장부가치 대 시장가치(BEME), 시장베타(BETA), 과거수익률(PRET), 단기수익률반전(REV), 고유변동성(IVOL)은 $\mathrm{CO}$ 와 양의 상관관계에 있고, 유동성(ILLIQ)은 $\mathrm{CO}$ 와 음의 상관관계가 나타난다. 거래량회전율 (TURN)은 $\mathrm{CO}$ 와 양의 상관관계에 있으나 그 크기가 작아 패널 $\mathrm{B}$ 에서 뚜렷한 패턴이 나타나지 않는다. 특히, $\mathrm{CO}$ 와 과거수익률(PRET), 단기수익률반전(REV)의 상관계수는 $0.351,0.356$ 으로 다른 요인에 비하여 높은 상관관계를 가진다. 우리는 제 4장에서 기업특성 요인의 영향이 $\mathrm{CO}$ 전략에 관여하는지 확인한다.

\section{4 포트폴리오 구성}

\subsection{1 단변량 포트폴리오}

본 연구에서는 Jegadeesh and Titman(1993)에 따라 중복 포트폴리오(overlapping portfolio)를 구성한다. 2000년 1월부터 2020년 6월까지 유가증권시장과 코스닥시장에 상장된 기업을 대상으로 매 $t$ 월의 시작시점에서 포트폴리오를 구성한다. 과거 $J$ 개월 $(t-J$ 월부터 $t-1$ 월)의 월별주식수익률과 월별거래대금을 이용하여 $t$ 월의 $\mathrm{CO}$ 를 계산한다. 본 연구에서는 과거 12 개월 주식데이터 $(J=12)$ 를 이용하여 $\mathrm{CO}$ 를 도출하며, 제 5 장 제 1 절에서 $J$ 기간의 변화에 따른 결과를 나타낸다. $\mathrm{CO}$ 를 기준으로 10 분위수 포트폴리오를 구성하여 CO 순위가 가장 낮은 $10 \%$ 에 Low 1 을 부여하고, 가장 높은 $10 \%$ 에 High 10 을 부여한다. CO전략의 수익성을 확인하기 위하여 투자자의 계속적 과잉반응이 극단적으로 나타나는 Low 1과 High 10에 초점을 맞춘다. 각 포트폴리오는 차후 $K$ 개월( $t+1$ 월부터 $t+K$ 월)동안 보유한다. Jegadeesh(1990)에 따라 월별주식 수익률의 음의 자기상관 효과를 줄이기 위해 $\mathrm{t}$ 월의 월별수익률과 거래대금을 제외하며, 포트 폴리오 구성기간(formation period, $J$ )와 보유기간(holding period, $K$ ) 사이에 1 개월의 간격을 둔다. 보유기간이 $\mathrm{K}$ 개월인 중복 포트폴리오에서 $t$ 월의 월별수익률은 $t-K$ 월부터 $t-1$ 월에 
한국증권학회지 제 50 권 1호 (2021)

구성된 포트폴리오의 월별수익률로 구성된다. 다시 말해, 매 $t$ 월에서는 $t-K$ 개월 이전뿐만 아니라 전월에 선택된 포트폴리오를 보유하게 된다. 이러한 중복 포트폴리오 구성방법은 <그림 $1>$ 에 자세히 나타낸다.

〈그림 1〉 중복 포트폴리오(overlapping portfolio)구성 방법

이 그림은 Jegadeesh and Titman(1993)에 따른 중복 포트폴리오 구성방법이다. 포트폴리오 구성기간이 3 개월 $(J=3)$ 이고, 보유기간이 3 개월 $(K=3)$ 일 경우 다음과 같은 방법으로 포트폴리오 수익률을 구성한다.
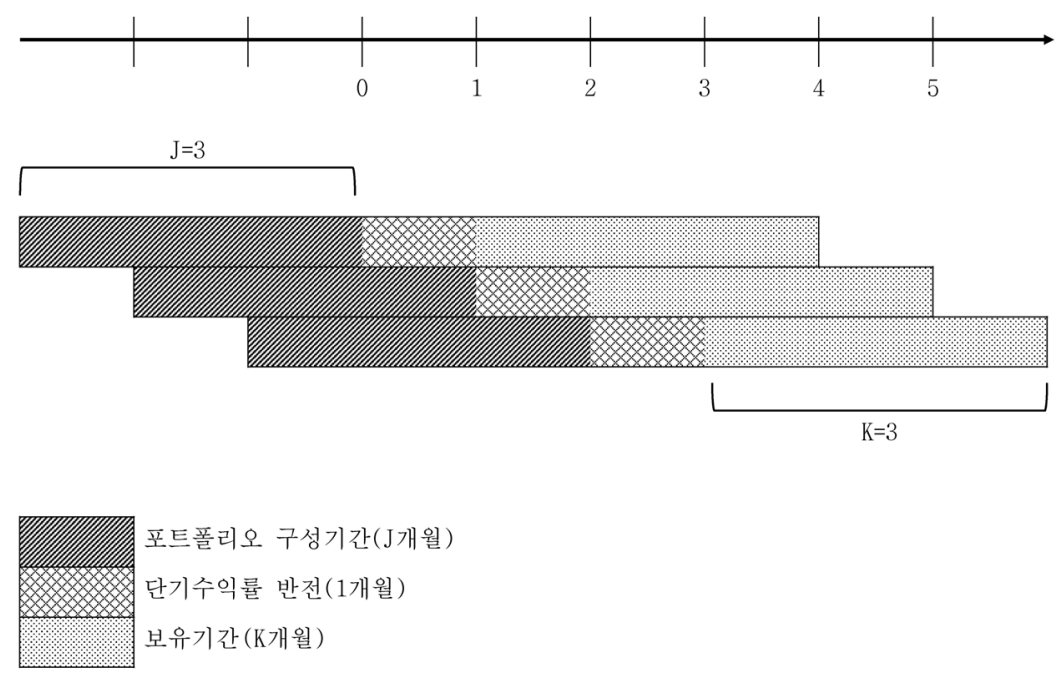

<그림 1 >은 포트폴리오 구성기간이 3 개월 $(J=3)$ 이고, 보유기간이 3 개월 $(K=3)$ 인 중복 포트폴리오의 구성방법이다. 포트폴리오 수익률은 매월 각 포트폴리오의 수익률에 $1 / K$ 의 가중치를 곱한 값의 합이다. 예를 들어, <그림 $1>$ 의 $t=3$ 일 때 수익률은 첫 번째 구성된 포트폴리오의 세 번째 달의 수익률과 두 번째 구성된 포트폴리오의 두 번째 달의 수익률, 세 번째 포트폴리오의 첫 번째 달의 수익률의 합을 $K=3$ 으로 나눈 값이 된다. 본 연구에서는 포트폴리오 구성기간을 12 개월로 설정하고, 보유기간은 6 개월, 9 개월 그리고 12 개월로 나누어 진행한다.

\section{4 .2 다변량 포트폴리오}

본 연구에서는 주식수익률과 $\mathrm{CO}$ 의 관계에서 기업특성 요인의 영향을 배제하기 위하여 다변량 포트폴리오 분석을 한다. 포트폴리오 구성방법은 다음과 같다. 매 $t$ 월 기업특성 요인을 기준으로 5 분위수 포트폴리오로 나눈다. 각 기업특성 포트폴리오에 속한 주식을 대상으로 다시 $\mathrm{CO}$ 에 따라 5 분위수 포트폴리오로 나누어 25 개 $(5 \times 5)$ 의 포트폴리오를 구성한다. 각 포트폴리오에 속한 주식은 차후 $\mathrm{K}$ 개월 $(t+1$ 월부터 $t+K$ 월 $)$ 동안 보유한다. 중복 포트폴리오의 구성은 <그림 $1>$ 과 동일하다. 위의 방법을 통하여 기업특성 요인을 통제한 후 주식수익률과 $\mathrm{CO}$ 의 관계를 조사한다. 다변량 포트폴리오 분석결과는 모든 기업특성 요인을 포함하기 위해 각 기업특성 포트폴리오에 걸친 CO 포트폴리오 평균수익률을 제시한다. 


\section{4. 실증결과}

\section{1 단변량 포트폴리오 분석}

<표 2>는 CO 기반 포트폴리오 수익률이다. 포트폴리오 1(Low 1)은 과거 12 개월의 월별 수익률과 월별거래대금으로 도출한 CO가 가장 낮은 그룹이고, 포트폴리오 10(High 10)은 CO가 가장 높은 그룹이다. $\mathrm{CO}$ 가 가장 낮은 포트폴리오 1 은 음의 정보에 대한 투자자의 계속적 과잉반응을 나타내고, 포트폴리오 10은 양의 정보에 대한 투자자의 계속적 과잉반응을 나타낸다. $\mathrm{CO}$ 는 식 (2)에 의하여 과거 12 개월 $(t-12$ 월부터 $t-1$ 월)의 월별수익률과 월별거래대금으로 도출한다. 각 열은 포트폴리오 구성 이후 보유기간(K)이 6개월, 9개월, 그리고 12 개월인 중복 포트폴리오 수익률이다. 중복 포트폴리오 구성방법은 <그림 1>과 같다. High-Low는 CO가 가장 높은 포트폴리오를 매입하고, $\mathrm{CO}$ 가 가장 낮은 포트폴리오를 매도하는 전략인 무비용 포트폴리오(zero-cost investment)의 수익률이다. CAPM 위험조정 수익률은 식 (3)의 $\alpha$ 이고, FF3 위험조정 수익률은 Fama and French(1993)의 3요인으로 위험이 조정된 수익률로 식 (6)의 $\alpha$ 이다. 괄호 안은 Newey and West(1987)의 t-통계량을 나타낸다.

$$
R_{i, t}-r_{f, t}=\alpha_{i}+\beta_{1, i}\left(R_{m, t}-r_{f, t}\right)+\beta_{2, t} S M B_{t}+\beta_{3, t} H M L_{t}+\epsilon_{i, t}
$$

$<$ 표 2>의 결과는 $\mathrm{CO}$ 와 주식수익률간의 양의 관계를 나타낸다. 음의 계속적 과잉반응을 가지는 포트폴리오(Low 1)는 다른 포트폴리오에 비하여 상대적으로 낮은 수익률을, 양의 계속적 과잉반응을 가지는 포트폴리오(High 10)는 상대적으로 높은 수익률을 가진다. 보유기간이 6개월, 9개월, 그리고 12 개월일 때 무비용 포트폴리오의 수익률은 $0.837 \%, 0.806 \%, 0.603 \%$ 이며 통계적으로 유의하다. $\mathrm{CO}$ 전략의 연간 수익률은 $7 \%$ 에서 $10 \%$ 사이이다. 따라서 계속적 과잉 반응을 통하여 수익성 있는 매입-매수 거래전략을 구현할 수 있음을 제시한다. 보유기간이 6 개월인 경우에 수익률이 가장 높으며, 보유기간이 9 개월일 때 가장 높은 $\mathrm{t}-$ 통계량을 가진다. 보유기간이 12 개월인 경우에도 여전히 통계적으로나 경제적으로 유의한 양의 수익률을 가진다.

<표 2>의 CAPM 위험조정수익률은 식 (3)에 따라 위험을 조정한 수익률이다. CAPM 무비용 포트폴리오는 각 보유기간에 따라 $0.804 \%, 0.789 \%, 0.601 \%$ 이며, 모든 기간에서 유의한 양의 값이다. FF3 위험조정 수익률은 Fama and French(1993)의 3요인 모형인 시장요인, 규모요인 (SMB), 가치요인(HML)으로 위험을 조정한 알파이다. 이를 통해 CO전략이 단지 위험부담에 대한 보상인지 여부를 검토할 수 있다. FF3 위험조정 수익률은 보유기간이 6개월, 9개월, 12 개월일 때 각각 $0.208 \%, 0.333 \%, 0.231 \%$ 로 유의한 양의 값이다. 따라서 Fama and French(1993)의 3요인 모형으로 위험을 조정하여도 $\mathrm{CO}$ 포트폴리오의 매수-매입전략에 수익성이 있음을 확인한다.

요약하면, 매월 말 $\mathrm{CO}$ 를 기준으로 10 분위수 포트폴리오를 구성하고 각 포트폴리오의 수익률을 $\mathrm{K}$ 개월 보유한 결과, 무비용 포트폴리오는 유의한 양의 수익률을 가진다. CAPM, FF3 위험조정 수익률도 유의한 양의 수익률을 가진다. 위험 요인을 추가할수록 포트폴리오 수익률은 감소하는 
한국증권학회지 제 50 권 1호 (2021)

경향이 있으나, 모든 수익률이 유의한 양의 값인 것을 확인한다. 따라서 우리는 $\mathrm{CO}$ 와 주식수익률은 유의한 양의 관계에 있고, $\mathrm{CO}$ 전략이 수익성을 가진다는 사실을 확인한다. 보유기간이 6개월 $(K=6)$ 일 경우에 수익률이 가장 높으므로 이후 포트폴리오 전략의 결과는 보유기간이 6개월인 경우만 나타낸다.

\section{〈표 2〉CO 기반 포트폴리오 수익률}

매월 말 $\mathrm{CO}$ 를 기준으로 구성한 10 개 포트폴리오 수익률이다. 포트폴리오 구성기간은 12 개월 $(J=12)$ 이며, 각 포트폴리오를 6 개월, 9 개월, 그리고 12 개월 보유한 포트폴리오 수익률이다. CAPM은 시장요인으로 위험을 조정한 수익률이고, FF3은 Fama and French(1993)의 3요인으로 위험을 조정한 수익률이다. 보유기간은 각각 6 개월 $(K=6), 9$ 개월 $(K=9), 12$ 개월 $(K=12)$ 이다. 수익률은 퍼센트 단위다. 표본은 2000 년 1 월부터 2020년 6월까지 유가증권시장과 코스닥시장에 상장된 보통주 중에서 주당 가격이 500 원보다 큰 주식이다. ${ }^{* * *}{ }^{* *}$, ${ }^{*}$ 는 각각 $1 \%, 5 \%, 10 \%$ 유의수준에서 유의함을 표시한다. 괄호 안의 숫자는 Newey and West(1987) $\mathrm{t}$-통계량이다.

\begin{tabular}{cccc}
\hline \multirow{2}{*}{ CO 포트폴리오 } & & $J=12$ & \\
\cline { 2 - 4 } Low 1 & $K=6$ & $K=9$ & $K=12$ \\
2 & 0.516 & 0.517 & 0.559 \\
3 & 0.656 & 0.721 & 0.747 \\
4 & 0.768 & 0.826 & 0.844 \\
5 & 0.901 & 0.911 & 0.912 \\
6 & 0.996 & 1.006 & 1.011 \\
7 & 1.136 & 1.114 & 1.080 \\
8 & 1.158 & 1.142 & 1.128 \\
9 & 1.223 & 1.209 & 1.167 \\
High 10 & 1.270 & 1.246 & 1.167 \\
High-Low & 1.353 & 1.323 & 1.162 \\
& $0.837^{* * *}$ & $0.806^{* * *}$ & $0.603^{* * *}$ \\
CAPM & $(4.374)$ & $(4.701)$ & $(3.760)$ \\
위험조정 수익률 & $0.804^{* * *}$ & $0.789^{* * *}$ & $0.601^{* * *}$ \\
FF3 & $(10.456)$ & $(10.769)$ & $(7.903)$ \\
위험조정 수익률 & $0.208^{* *}$ & $0.333^{* * *}$ & $0.231^{* * *}$ \\
\end{tabular}

\section{2 모멘텀과 계속적 과잉반응}

Jegadeesh and Titman(1993)의 모멘텀 이상현상은 주식시장에서 가장 유명한 이상수익률 현상 중 하나다. Rouwenhorst(1998)에 따르면 1980년과 1995년 사이에 모멘텀 전략은 수익성을 가지며 12 개 국가에서 일관되고 평균 1년간 지속적인 수익률을 가진다. Griffin et al.(2003)은 거시 경제적 위험이 모멘텀 전략의 이익을 설명할 수 있는지 여부를 검토하고, 모멘텀 전략이 국제시장에서 상당한 양의 이익을 창출함을 보인다. 반면, 국내 주식시장에서는 모멘텀에 대한 결과가 상이하게 나타난다. Kam and Shin(2011)에 따르면 주가 모멘텀에 따라 구성된 포트폴리오에서 패자포트폴리오의 수익률이 승자포트폴리오보다 높다. 이는 역행투자전략 (constrain investment strategy)의 성과에서 유의한 양 $(+)$ 의 수익률을 가짐을 의미한다. 
Empirical Investigation of the Relationship between Continuing Overreaction and Stock Returns

$\operatorname{Jang}$ (2017)은 과거 12 개월의 기간을 과거 6 개월을 기준으로 나누어 모멘텀 효과를 분석한다. 그 결과 중기 과거 6 개월의 승자를 매수하고 패자를 매도하는 전략에서 $1.51 \%$ 수익률을 가진다. $\operatorname{Eom}(2013)$ 에 따르면 국내 주식시장에서 전반적으로 모멘텀이 존재하지 않는다. 분석종목과 기간을 세부적으로 나누어 분석한 결과, 외환위기 이전에는 음의 모멘텀이 나타나고 외환위기 이후에는 양의 모멘텀이 존재함을 확인한다.

Daniel et al.(1998)에 따르면 Byun et al.(2016)에서 제시한 계속적 과잉반응(CO)은 모멘텀 전략에 대한 대표적인 행동설명 중 하나다. 과거수익률에 기초한 수익률 예측성이 계속적 과잉반응에 의한 것이라면 계속적 과잉반응은 과거수익률보다 미래수익률을 더 잘 예측하게 될 것이다. 이에 따라 본 절에서는 $\mathrm{CO}$ 전략과 모멘텀 전략의 수익성을 비교한다.

우리는 $\mathrm{CO}$ 전략과 모멘텀 전략에 따른 포트폴리오 수익률을 비교한다. 서로 다른 전략의 수익률을 기준(benchmark)으로 사용하여 기준에 의해 조정된 포트폴리오 수익률을 기준 조정수익률(benchmark-adjusted return)로 나타낸다. <표 3>의 1-3열은 CO 포트폴리오의 수익률을 나타낸다. 월별수익률은 CO가 가장 낮은 Low 1 부터 가장 높은 High 10 의 수익률을 의미하고, 모멘텀 조정수익률은 $\mathrm{CO}$ 포트폴리오에 속한 주식의 수익률에서 각 주식이 속한 모멘텀 포트폴리오의 동일가중 수익률을 뺀 값이다. <표 3>의 4-6열은 모멘텀 포트폴리오의 수익률을 나타낸다. 월별수익률은 모멘텀이 가장 낮은 Low 1 부터 가장 높은 High 10 의 수익률을 의미하고, $\mathrm{CO}$ 조정 수익률은 모멘텀 포트폴리오에 속한 주식의 수익률에서 각 주식이 속한 $\mathrm{CO}$ 포트폴리오의 동일가중 수익률을 감한 값이다.

\section{〈표 3〉 $\mathrm{CO}$, 모멘텀 포트폴리오의 기준조정 수익률}

이 표는 보유기간이 6 개월 $(K=6)$ 인 $\mathrm{CO}$ 포트폴리오와 모멘텀 포트폴리오의 기준조정 수익률 결과다. 모멘텀(CO)조정 수익률은 매월 말 $\mathrm{CO}$ (모멘텀)를 기준으로 구성된 포트폴리오 수익률에서 그 주식이 속한 모멘텀 $(\mathrm{CO}) 10$ 분위수 포트폴리오의 수익률을 감한 값이다. 보유기간은 6 개월 $(K=6)$ 이고, 수익률은 퍼센트 단위다. 표본은 2000년 1월부터 2020년 6월까지 유가증권시장과 코스닥시장에 상장된 보통주 중에서 주당 가격이 500 원보다 큰 주식이다. ${ }^{* * *},{ }^{* *},{ }^{*}$ 는 각각 $1 \%, 5 \%, 10 \%$ 유의수준에서 유의함을 표시한다. 괄호 안의 숫자는 Newey and West(1987) t-통계량이다.

\begin{tabular}{|c|c|c|c|c|c|c|c|}
\hline \multicolumn{2}{|c|}{$\begin{array}{c}\mathrm{CO} \\
\text { 포트폴리오 }\end{array}$} & \multirow{2}{*}{$\begin{array}{c}\text { 월별수익률 } \\
0.516\end{array}$} & \multirow{2}{*}{$\begin{array}{c}\begin{array}{c}\text { 모멘텀 } \\
\text { 조정수익률 }\end{array} \\
-0.243\end{array}$} & \multicolumn{2}{|c|}{$\begin{array}{c}\text { 모멘텀 } \\
\text { 포트폴리오 }\end{array}$} & \multirow{2}{*}{$\begin{array}{c}\text { 월별수익률 } \\
-0.225\end{array}$} & \multirow{2}{*}{$\begin{array}{c}\mathrm{CO} \\
\text { 조정수익률 } \\
-1.017\end{array}$} \\
\hline Low & 1 & & & \multirow[t]{9}{*}{ Low } & 1 & & \\
\hline & 2 & 0.656 & -0.175 & & 2 & 0.671 & -0.196 \\
\hline & 3 & 0.768 & -0.128 & & 3 & 1.063 & 0.149 \\
\hline & 4 & 0.901 & -0.059 & & 4 & 1.237 & 0.294 \\
\hline & 5 & 0.996 & -0.015 & & 5 & 1.252 & 0.264 \\
\hline & 6 & 1.136 & 0.081 & & 6 & 1.359 & 0.334 \\
\hline & 7 & 1.158 & 0.072 & & 7 & 1.340 & 0.292 \\
\hline & 8 & 1.223 & 0.115 & & 8 & 1.272 & 0.186 \\
\hline & 9 & 1.270 & 0.149 & & 9 & 1.182 & 0.062 \\
\hline High & & 1.353 & 0.257 & \multirow{3}{*}{\multicolumn{2}{|c|}{$\begin{array}{l}\text { High } 10 \\
\text { High-Low }\end{array}$}} & 0.802 & -0.336 \\
\hline \multirow{2}{*}{\multicolumn{2}{|c|}{ High-Low }} & $0.837^{* * * *}$ & $0.500^{* * *}$ & & & $1.027^{* * *}$ & $0.681^{* *}$ \\
\hline & & $(4.374)$ & (3.808) & & & $(3.155)$ & $(2.510)$ \\
\hline
\end{tabular}


한국증권학회지 제 50 권 1호 (2021)

<표 3>에 따르면, CO 포트폴리오의 수익률은 0.837\%, 모멘텀 포트폴리오의 수익률은 1.027\% 이다. $\mathrm{t}$-통계량을 비교하면 CO 포트폴리오와 모멘텀 포트폴리오는 각각 4.374와 3.155로 CO 포트폴리오가 더 높다. 즉, $\mathrm{CO}$ 전략이 더 높은 샤프비율(sharpe ratio)을 가진다. $\mathrm{CO}$ 포트폴리오의 경우 $\mathrm{CO}$ 가 증가함에 따라 수익률이 단조롭게 증가하는 패턴을 가지지만, 모멘텀 포트폴리오의 경우 포트폴리오 7 부터 포트폴리오 10 에 걸쳐 하락하는 추세를 가진다. <표 $3>$ 에서 중요한 것은 기준조정 수익률이다. CO 포트폴리오의 기준조정 수익률의 차이는 $0.500 \%$ 이고, 모멘텀 포트폴리오의 기준조정 수익률의 차이는 $0.681 \%$ 이다. $\mathrm{CO}$ 포트폴리오의 기준조정 수익률과 모멘텀 포트폴리오의 기준조정 수익률은 모두 유의한 양의 수익률을 가진다. 하지만, 두 포트

〈그림 2〉 CO 포트폴리오와 모멘텀 포트폴리오의 비교

이 그림은 CO 포트폴리오와 모멘텀포트폴리오를 비교한다. 그룹 A는 2000 2010년과 2011 2020년의 포트폴리오 수익률이며, 그룹 B는 2000 2010년과 2011 2020년의 CO 포트폴리오와 모멘텀 포트폴리오의 기준조정 수익률을 나타낸다. 수익률은 퍼센트 단위다. 표본은 2000년 1월부터 2020년 6월까지 유가증권 시장과 코스닥시장에 상장된 보통주 중에서 주당 가격이 500원보다 큰 주식이다.

그룹 A: 포트폴리오 수익률

2000 2010년

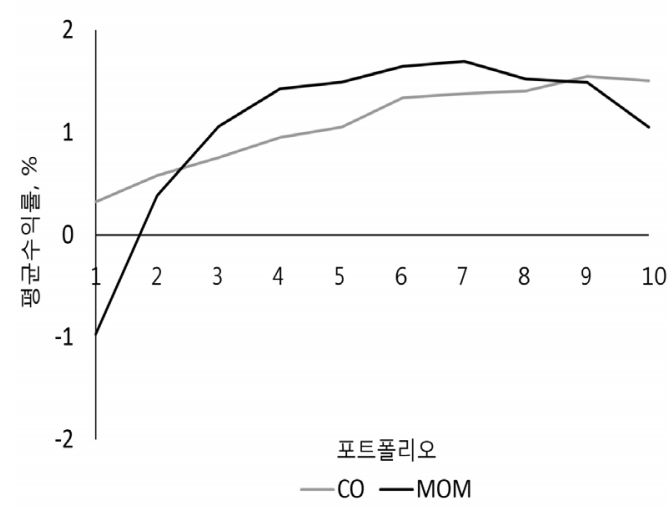

2011 2020년

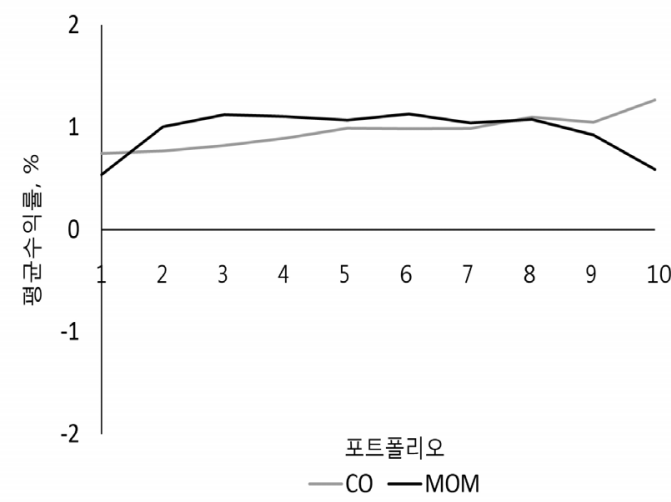

그룹 B: 기준조정 수익률
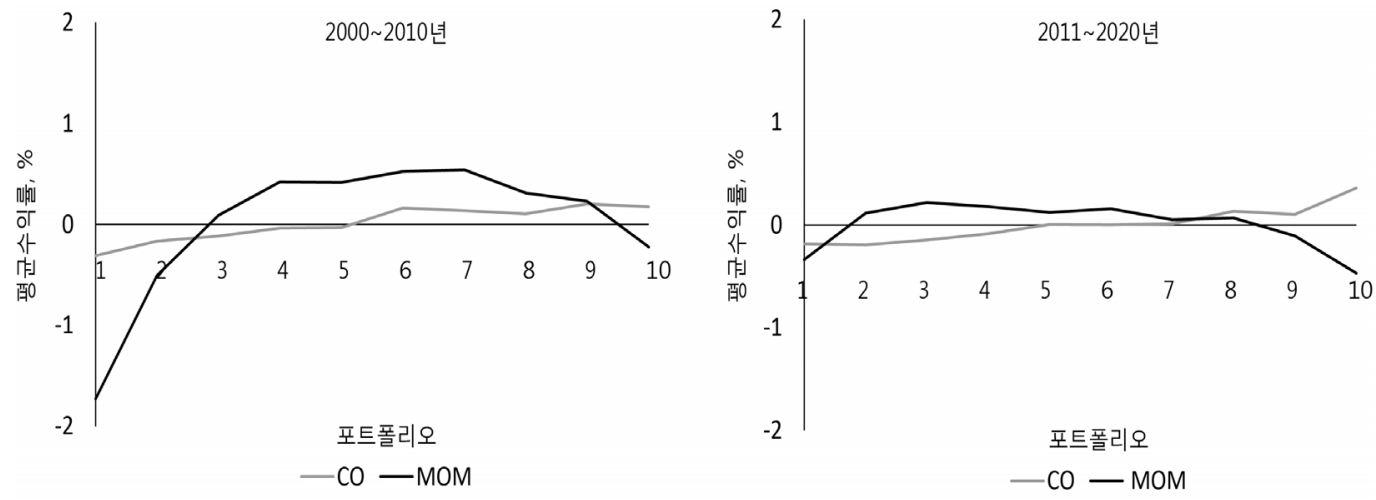
Empirical Investigation of the Relationship between Continuing Overreaction and Stock Returns

폴리오의 패턴은 놀라울 정도로 다르다. $\mathrm{CO}$ 포트폴리오의 기준조정 수익률은 $\mathrm{CO}$ 가 높음에 따라 단조롭게 상승하는 수익률은 가지는 반면, 모멘텀 포트폴리오의 기준조정 수익률은 증가하는 패턴을 가지지 않고 포트폴리오 7에서부터 하락하는 추세를 가진다. 또한, $\mathrm{CO}$ 포트폴리오의 기준조정 수익률이 모멘텀 포트폴리오의 기준조정 수익률보다 높은 $\mathrm{t}$-통계량을 가진다.

우리는 위의 결과를 표본기간을 나누어 재확인한다. <그림 2>는 2000년부터 2010년과 2011년부터 2020년의 CO 포트폴리오와 모멘텀 포트폴리오의 수익률을 비교한다. <그림 2>의 그룹 A는 2000년부터 2010년까지의 포트폴리오 수익률과 2011년부터 2020년까지의 포트폴리오 수익률을 나타낸다. $\mathrm{CO}$ 포트폴리오는 $\mathrm{CO}$ 가 증가함에 따라 수익률이 단조롭게 증가하는 패턴을 가진다. 하지만, 모멘텀 포트폴리오는 뚜렷한 패턴을 나타내지 않는다. 그룹 B는 2000년부터 2010년과 2011년부터 2020년의 기준조정 수익률을 나타낸다. 그룹 A와 유사하게, CO 포트 폴리오는 $\mathrm{CO}$ 에 따라 증가하는 수익률 패턴을 확인할 수 있지만, 모멘텀 포트폴리오는 패턴을 가지지 않는다. 2011년부터 2020년의 결과에서 모멘텀 포트폴리오 10은 포트폴리오 1과 유사한 수익률을 가지므로 모멘텀 전략은 양의 수익률을 가지지 못한다.

정리하면, 과거 12 개월의 포트폴리오 구성기간을 가지고 동일한 보유기간을 가지는 모멘텀 전략과 $\mathrm{CO}$ 전략은 모두 유의한 양의 수익률을 가진다. $\mathrm{CO}$ 를 조정한 모멘텀전략은 뚜렷한 패턴을 가지지 않지만, 국내 주식시장에서 모멘텀으로 조정한 $\mathrm{CO}$ 전략은 여전히 유의한 양의 수익률을 가진다. 따라서 $\mathrm{CO}$ 전략의 수익률은 모멘텀 전략에 의한 기인한 것이 아니며 모멘텀전략은 $\mathrm{CO}$ 으로 인해 수익률과 유의도가 낮아짐을 확인한다.

\section{3 다변량 포트폴리오 분석}

본 절에서는 시장베타(BETA), 기업규모(SIZE), 장부가치 대 시장가치(BEME), 과거수익률 (PRET), 단기수익률반전(REV), 유동성(ILLIQ), 고유변동성(IVOL), 거래량회전율(TURN)을 통제한 후, 계속적 과잉반응과 주식수익률의 관계를 검토한다. 먼저, 시장베타(BETA)를 기준으로 5 분위수 포트폴리오를 구성한다. 각 시장베타 포트폴리오 내에서 다시 $\mathrm{CO}$ 를 기준으로 가장 낮은 Low 1 부터 가장 높은 High 5 까지 순위를 매겨 5 분위수 포트폴리오로 나눈다. 간결성을 위해 25개(5×5)포트폴리오를 모두 보고하지 않고, 각 시장베타 포트폴리오에 속한 Low $1(\mathrm{CO})$ 부터 High 5(CO)까지의 평균수익률을 제시한다. 다시 말해, 시장베타(BETA) 포트폴리오 Low 1 에 속한 주식을 대상으로 다시 $\mathrm{CO}$ 를 기준으로 5 분위수 포트폴리오를 나눈다. 시장베타 (BETA)가 Low 1이면서 CO가 Low 1인 포트폴리오는 B1-C1이 되고, 시장베타(BETA)가 Low 1인 포트폴리오는 B1-C1부터 B1-C5까지 5개 포트폴리오로 분류된다. 위와 같은 과정을 BETA 2, ..., 5까지 반복하면 총 25개의 포트폴리오가 구성된다. <표 4>에서 Low 1은 각 시장베타 포트폴리오에서 CO가 Low 1인 포트폴리오의 평균수익률이며 $\mathrm{B} 1-\mathrm{C} 1, \ldots, \mathrm{B} 5-\mathrm{C} 1$ 의 평균 수익률이다. 이러한 방법은 유사한 시장베타를 가진 CO 포트폴리오를 구성하므로 시장베타를 통제한 후 주식수익률에 대한 $\mathrm{CO}$ 의 영향을 나타낸다. 다변량 포트폴리오 분석에서 포트폴리오 구성기간이 과거 12 개월 $(J=12)$ 이고 보유기간이 6 개월 $(K=6)$ 인 결과를 제시한다. 
한국증권학회지 제 50 권 1 호 (2021)

〈표 4〉기업특성 요인을 통제 간 CO 포트폴리오의 수익률

이 표는 기업특성 요인을 통제한 $\mathrm{CO}$ 포트폴리오의 수익률이다. 매월 말 표본 내 모든 주식을 기업특성 요인을 기준으로 5 분위수 포트폴리오를 나누고, 각 포트폴리오의 주식을 $\mathrm{CO}$ 로 다시 정렬하여 5 분위수 포트폴리오를 만든다. 25개의 포트폴리오 중에서 각 기업특성 요인에 속한 주식을 평균하여 구성한 $\mathrm{CO}$ 포트폴리오의 결과를 나타낸다. CAPM은 시장요인으로 위험을 조정한 수익률이고, FF3은 Fama and French(1993)의 3요인으로 위험을 조정한 수익률이다. 보유기간은 6 개월 $(K=6)$ 이고, 수익률은 퍼센트 단위다. 표본은 2000년 1월부터 2020년 6월까지 유가증권시장과 코스닥시장에 상장된 보통주 중에서 주당 가격이 500 원보다 큰 주식이다. ${ }^{* * *},{ }^{* *}$, *는 각각 $1 \%, 5 \%, 10 \%$ 유의수준에서 유의함을 표시한다. 괄호 안의 숫자는 Newey and West(1987) t-통계량이다.

\begin{tabular}{|c|c|c|c|c|c|c|c|c|}
\hline $\begin{array}{c}\mathrm{CO} \\
\text { 포트폴리오 }\end{array}$ & BETA & SIZE & BEME & PRET & REV & ILLIQ & IVOL & TURN \\
\hline Low 1 & 0.647 & 0.620 & 0.734 & 0.750 & 0.659 & 0.598 & 0.675 & 0.732 \\
\hline 2 & 0.892 & 0.913 & 0.921 & 0.947 & 0.866 & 0.878 & 0.879 & 0.898 \\
\hline 3 & 1.070 & 1.100 & 1.103 & 1.060 & 1.055 & 1.046 & 1.027 & 1.080 \\
\hline 4 & 1.183 & 1.215 & 1.171 & 1.196 & 1.222 & 1.218 & 1.163 & 1.171 \\
\hline High 5 & 1.368 & 1.315 & 1.233 & 1.211 & 1.358 & 1.421 & 1.416 & 1.280 \\
\hline High-Low & $\begin{array}{c}0.721^{* * * *} \\
(5.038)\end{array}$ & $\begin{array}{c}0.695^{* * *} \\
(4.888)\end{array}$ & $\begin{array}{c}0.498^{* * *} \\
(3.713)\end{array}$ & $\begin{array}{c}0.461^{* * *} \\
(4.584)\end{array}$ & $\begin{array}{c}0.699^{* * *} \\
(5.292)\end{array}$ & $\begin{array}{c}0.823^{* * *} \\
(5.833)\end{array}$ & $\begin{array}{c}0.741^{* * *} \\
(5.124)\end{array}$ & $\begin{array}{c}0.548^{* * *} \\
(3.975)\end{array}$ \\
\hline $\begin{array}{l}\text { CAPM } \\
\text { 위험조정 } \\
\text { 수익률 }\end{array}$ & $\begin{array}{c}0.711^{* * *} \\
(11.072)\end{array}$ & $\begin{array}{c}0.700^{* * *} \\
(11.300)\end{array}$ & $\begin{array}{c}0.453^{* * *} \\
(10.739)\end{array}$ & $\begin{array}{c}0.395^{* * *} \\
(11.161)\end{array}$ & $\begin{array}{c}0.682^{* * *} \\
(12.576)\end{array}$ & $\begin{array}{c}0.835^{* * *} \\
(13.175)\end{array}$ & $\begin{array}{c}0.722^{* * *} \\
(14.009)\end{array}$ & $\begin{array}{c}0.516^{* * *} \\
(14.820)\end{array}$ \\
\hline $\begin{array}{l}\mathrm{FF} 3 \\
\text { 위험조정 } \\
\text { 수익률 }\end{array}$ & $\begin{array}{c}0.224^{\text {*** }} \\
(3.290)\end{array}$ & $\begin{array}{c}0.273^{\text {*** }} \\
(4.174)\end{array}$ & $\begin{array}{c}0.198^{\text {*** }} \\
(3.074)\end{array}$ & $\begin{array}{r}0.060 \\
(1.386)\end{array}$ & $\begin{array}{c}0.270^{\text {*** }} \\
(4.650)\end{array}$ & $\begin{array}{c}0.255^{\text {*** }} \\
(3.690)\end{array}$ & $\begin{array}{c}0.280^{\text {*** }} \\
(4.246)\end{array}$ & $\begin{array}{c}0.197^{* * *} \\
(2.988)\end{array}$ \\
\hline
\end{tabular}

시장베타(BETA)로 포트폴리오를 구성한 경우, $\mathrm{CO}$ 전략의 수익률은 $0.721 \%$ 로 유의한 양의 값이다. $\mathrm{CO}$ 포트폴리오의 수익률은 $\mathrm{CO}$ 가 증가함에 따라 단조롭게 증가한다. $\mathrm{CAPM}$ 와 FF3 위험조정 수익률은 $0.711 \%, 0.224 \%$ 로 유의한 양의 수익률이다. 따라서 시장베타는 CO전략에 유의한 영향을 미치지 못하며, $\mathrm{CO}$ 은 시장베타의 영향에서 독립적이라는 사실을 확인한다.

기업규모(SIZE)를 통제한 후, CO가 낮은 포트폴리오와 높은 포트폴리오의 차이는 $0.695 \%$ 로 유의한 양의 수익률이다. $\mathrm{CO}$ 가 증가함에 따라 수익률이 단조롭게 증가하는 패턴을 가진다. CAPM, FF3에 따른 위험조정 수익률은 각각 $0.700 \%, 0.273 \%$ 로 모두 유의한 양의 수익률이므로 $\mathrm{CO}$ 전략이 기업규모에 기인하지 않음을 확인한다. 다시 말해, 기업규모는 $\mathrm{CO}$ 가 높은(낮은) 주식일수록 높은(낮은) 수익률을 가지는 현상을 설명하지 않는다.

장부가치 대 시장가치(BEME)를 통제한 후 결과도 위와 유사하다. <표 4>에 따르면 $\mathrm{BEME}$ 를 통제한 후 CO 포트폴리오의 수익률은 단조롭게 증가한다. 무비용 포트폴리오의 수익률은 $0.498 \%$ 로 유의한 양의 값이다. 또한, CAPM, FF3에 따라 위험이 조정된 수익률은 각각 $0.453 \%$, $0.198 \%$ 로 유의한 양의 수익률이다. 장부가치 대 시장가치를 통제한 경우 기업규모를 통제할 때보다 $\mathrm{CO}$ 전략의 수익률이 낮지만, $\mathrm{CO}$ 전략은 여전히 유의한 양의 수익률을 가진다.

다음으로, 과거수익률(PRET)을 통제한 결과다. <표 1>의 패널 $\mathrm{C}$ 에 따르면 $\mathrm{CO}$ 는 PRET와 양의 상관관계를 가진다. 하지만, <표 $3>$ 을 통해 CO 포트폴리오의 모멘텀 조정수익률은 단조롭게 
Empirical Investigation of the Relationship between Continuing Overreaction and Stock Returns

증가하는 패턴을 가지고 무비용 포트폴리오는 유의한 양의 값임을 확인한다. Daniel et al.(1998)에 따르면 계속적 과잉반응이 모멘텀 현상을 야기한다. 다시 말해, 계속적 과잉반응과 모멘텀은 서로 영향을 미치는 관계이다. 우리는 계속적 과잉반응과 모멘텀이 서로 유의한 영향을 미치는 관계인지 여부를 확인하기 위하여 Fama and French(2015, 2017), Barillas and Shanken (2018)에 따라 CO와 모멘텀에 대한 스패닝 검정을 진행한다. Fama and French(2015, 2017)의 스패닝 검정은 한 검정요인(factor)을 종속변수로 취하고 다른 요인들을 독립변수로 취하는 방식이다. 회귀분석의 절편이 통계적으로 유의하지 않다면 그 검정요인은 다른 요인들에 의하여 스팬(spanned)되고, 검정요인은 주식수익률을 설명하는데 있어 불필요한(redundant) 요인이라 해석한다. <표 $\mathrm{A} 1>$ 은 $\mathrm{CO}$ 와 모멘텀의 스패닝 검정 결과다. <표 $\mathrm{A} 1>$ 의 모형 1 에서 모형 3 은 모멘텀을 종속변수로, 모형 4부터 모형 6은 계속적 과잉반응을 종속변수로 취한 결과다. <표 $\mathrm{A} 1>$ 에 따르면 모멘텀 $(\mathrm{CO})$ 을 종속변수로 하고 $\mathrm{CAPM}, \mathrm{FF} 3$, 그리고 $\mathrm{CO}$ (모멘텀)를 독립변수로 취한 결과에서 모멘텀 $(\mathrm{CO})$ 의 비정상적 수익률(alpha)은 유의한 양의 값이다. 특히, 모형 3(6)에서 $\mathrm{CO}$ (PRET)의 회귀계수는 0.963(0.500)으로 유의한 양의 값이다. 더 나아가, 서로 다른 변수를 회귀분석에 포함한 모형 3 과 모형 6 에서 결정계수의 값이 급격하게 증가한다. 따라서 모멘텀과 계속적 과잉반응은 서로 유의한 양의 영향을 미치는 관계다. 즉, <표 $4>$ 의 모멘텀을 통제한 결과는 상대적으로 낮은 수익률과 $\mathrm{t}$-통계량을 가질 것이라 예상할 수 있다. 모멘텀을 통제한 $\mathrm{CO}$ 전략의 수익률은 $0.461 \%$ 로 유의한 양의 값을 가진다. 또한, $\mathrm{CAPM}, \mathrm{FF} 3$ 위험조정 수익률은 각각 $0.395 \%, 0.060 \%$ 로 다른 기업특성 요인을 통제한 경우에 비하여 낮은 수익률을 가진다. 그 중, $\mathrm{CAPM}$ 위험조정 수익률은 유의한 양의 값이다. <표 $\mathrm{A} 1>$ 에 따르면 계속적 과잉반응과 모멘텀은 서로 긴밀한 관계를 가진다. 따라서 과거수익률은 투자자의 계속적 과잉반응의 FF3 위험조정 수익률에 대해 영향을 미친다. 하지만, 과거수익률을 통제한 후에도 CO 포트폴리오는 단조롭게 증가하는 패턴을 가지므로 $\mathrm{CO}$ 와 주식수익률간의 관계는 과거수익률에 기인한 결과가 아님을 확인한다.

$<$ 표 4>의 6 열은 단기수익률반전(REV)을 통제한 경우다. <표 $1>$ 의 패널 $\mathrm{C}$ 에 따르면 $\mathrm{CO}$ 와 $\mathrm{REV}$ 의 상관관계는 0.356 으로 상대적으로 큰 양의 값이다. 그럼에도 불구하고, 포트폴리오 수익률의 차이는 $0.699 \%$ 로 유의한 양의 값이며, 포트폴리오 수익률은 $\mathrm{CO}$ 에 따라 증가하는 패턴을 가진다. $\mathrm{CAPM}$ 과 $\mathrm{FF} 3$ 위험조정 수익률은 $0.682 \%, 0.270 \%$ 로 통계적으로 유의하다. 단기수익률반전은 $\mathrm{CO}$ 와 양의 상관관계를 가지지만, $\mathrm{CO}$ 전략의 수익성에 유의한 영향을 미치지 못한다.

$<$ 표 4>의 7열은 Amihud(2002)의 유동성(ILLIQ)을 통제한 결과다. <표 1>에 따르면 ILLIQ와 $\mathrm{CO}$ 는 음의 상관관계를 가지고 있다. $\mathrm{CO}$ 는 유동성의 변화에 크게 요동하지 않으며, $\mathrm{CO}$ 전략의 수익률은 $0.823 \%$ 로 유의하다. 각 위험조정 수익률의 차이는 $0.835 \%, 0.255 \%$ 로 유의한 양의 값이다. 따라서 유동성은 $\mathrm{CO}$ 와 미래 주식수익률 사이의 양의 관계를 설명하지 않는다.

다음은 식 (5)로 도출된 고유변동성(IVOL)을 통제한 결과다. 무비용 포트폴리오는 $0.741 \%$ 로 유의한 양의 수익률을 가진다. CAPM, FF3 위험조정 수익률은 각각 $0.722 \%, 0.280 \%$ 로 유의한 값이다. 따라서 $\mathrm{IVOL}$ 은 $\mathrm{CO}$ 와 주식수익률 간의 관계를 충분히 설명하지 못한다. 
한국증권학회지 제 50 권 1 호 (2021)

$<$ 표 4>의 마지막 열은 거래량회전율(TURN)을 통제한 결과이다. <표 1>에서 과거 12 개월의 평균 회전율과 $\mathrm{CO}$ 간의 관계를 확인한 결과, $\mathrm{CO}$ 는 $\mathrm{TURN}$ 과 양의 상관관계에 있지만 그 값은 0.017 로 현저히 낮다. 거래량 회전율을 제어한 후 CO전략의 수익률은 $0.548 \%$ 이며 CAPM, $\mathrm{FF} 3$ 위험조정 수익률은 각각 $0.516 \%, 0.197 \%$ 로 유의한 양의 값이다.

본 절에서는 기업특성을 나타내는 요인인 시장베타(BETA), 기업규모(SIZE), 장부가치 대 시장가치(BEME), 과거수익률(PRET), 단기수익률반전(REV), 유동성(ILLIQ), 고유변동성 (IVOL), 거래량회전율(TURN)을 통제한 후 CO전략의 수익성을 확인한다. 그 결과, 기업특성 요인을 통제하여도 $\mathrm{CO}$ 전략은 유의한 양의 수익률을 유지한다. 계속적 과잉반응이 높은(낮은) 주식일수록 투자자에게 저평가(고평가)되어 높은(낮은) 주식수익률을 가지는 현상은 기업특성 요인을 통제하여도 유지된다. 다시 말해, 계속적 과잉반응과 주식수익률 간의 유의한 양의 관계는 기업특성 요인에 기인하는 현상이 아니다. 따라서 CO 포트폴리오에 대하여 시장베타, 시장규모, 장부가치 대 시장가치, 과거수익률, 단기수익률반전, 유동성, 고유변동성, 거래량회전율의 효과로는 높은 $\mathrm{CO}$ 주식에 대한 높은 수익률을 설명할 수 없다.

\section{4 계속적 과잉반응과 수익률 지속성, 정보의 불연속성의 관계}

기존의 연구들은 주식시장에서 수익률 지속성(return consistency)의 역할과 정보의 불연속성 (information discreteness)을 조사했다. Grinblatt and Moskowitz(2004)에 따르면 양의 과거수익률의 지속성은 기대수익률에 횡단면적으로 유의한 영향을 미친다. Watkins(2006)에 따르면 과거 2주 동안 꾸준하게 양의(음의) 수익률을 가진 주식은 그렇지 않은 주식에 비하여 높은(낮은) 미래수익률을 가진다. 단기 수익률의 지속성을 이용한 전략은 시간이 지남에 따라 유의하다. Alwathainani(2009)는 기업의 과거 재무성과의 성장지속성을 통해 미래수익률을 예측할 수 있다고 주장한다. 이러한 관계는 고성장 기업에 비하여 저성장 기업에서 더욱 강하게 나타난다. Da et al.(2014)은 포트폴리오 구성기간동안 발생한 일별 수익률의 부호를 이용하여 정보의 흐름이 연속적인지 여부를 확인한다. 정보의 흐름에 대한 측정치는 정보의 불연속성 (information discreteness, ID)으로 나타낸다. Da et al.(2014)에 따르면, 연속적인 정보는 강한 수익률 지속성을 야기한다. Lin et al.(2016)은 ID로 과거수익률에 내재된 연속적인 정보를 식별하여 대만주식시장에 존재하는 투자자의 과소반응을 설명한다. 종합하면, 동일한 방향으로 연속되는 수익률을 가진 주식의 경우 극단적인 CO 포트폴리오에 속하는 경향이 있고, 높은 수준의 수익률 지속성과 낮은 수준의 정보 불연속을 가질 가능성이 있다고 예상할 수 있다. 본 절에서 우리는 $\mathrm{CO}$ 의 효과가 수익률 지속성 또는 정보의 불연속성에 기인하는지 여부를 확인한다.

Grinblatt and Moskowitz(2004)는 수익률 지속성 가변수로 POS_RC와 NEG_RC를 제시한다. 과거 12 개월의 수익률이 양(음)의 값인 주식을 대상으로 과거 양(음)의 수익률을 적어도 8 개월 이상 경험했다면 POS_RC(NEG_RC)에 1을 부여한다. CO변수는 월별 부호화된 거래량을 사용하기 때문에, 양의 수익률을 가지는 개월의 수와 음의 수익률을 가지는 개월의 수는 수익률 지속성의 효과를 잘 나타낼 것이다. 
Empirical Investigation of the Relationship between Continuing Overreaction and Stock Returns

더 나아가, 계속적 과잉반응 전략의 수익성이 포트폴리오 구성기간 동안 양의(음의) 월별 수익률을 가진 달의 개수에 의한 것인지 여부를 확인하기 위해 다변량 포트폴리오 분석을 진행한다. 다변량 포트폴리오는 $\mathrm{CO}$ 변수와 양의 수익률을 가지는 달의 개수에서 음의 수익률을 가지는 달의 개수를 뺀 NPOS_NEG로 구성된다. <표 5>의 패널 A는 CO와 과거 12 개월의 수익률 중 양의 수익률을 가진 달의 개수에서 음의 수익률을 가진 달의 개수를 뺀(NPOS_NEG) 변수를 이용한 다변량 포트폴리오 결과다. 매월 NPOS_NEG를 기준으로 하위 $30 \%$ 에 속하는 주식을 포트폴리오 1, 상위 30\%에 속하는 주식을 포트폴리오 3에 부여하고, 두 포트폴리오에 속하지 않는 중간 $40 \%$ 의 주식에 포트폴리오 2 를 부여한다. 각 NPOS_NEG 포트폴리오에 속한 주식을 대상으로 $\mathrm{CO}$ 에 따른 5분위수 포트폴리오로 나눈다. $\mathrm{CO}$ 가 가장 낮은 포트폴리오에 Low 1을, 가장 높은 포트폴리오에 High 5 를 부여한다. 그 결과, $\mathrm{CO}$ 가 높은 포트폴리오를 매입하고 $\mathrm{CO}$ 가 낮은 포트폴리오를 매도하는 전략은 각 NPOS_NEG 포트폴리오에서 $0.561 \%, 0.539 \%, 0.549 \%$ 로

〈표 5〉 추가적인 변수를 통제한 CO 포트폴리오의 수익률

이 표는 포트폴리오 구성기간 동안 양과 음의 월별수익률을 가진 달의 개수와 정보의 불연속성(ID)을 통제한 후 $\mathrm{CO}$ 로 구성한 포트폴리오 수익률이다. 패널 $\mathrm{A}$ 는 양의 수익률을 가지는 달의 수에서 음의 수익률을 가지는 달의 수를 뺀(NPOS_NEG) 변수를 통제한 CO 포트폴리오의 수익률이다. 패널 B는 과거 12 개월의 일별 누적수익률 부호에 음의 수익률을 가진 날의 비율과 양의 수익률을 가진 날의 비율의 차이를 곱한 $\mathrm{ID}$ 를 통제한 포트폴리오 수익률이다. 보유기간은 6 개월 $(K=6)$ 이고, 수익률은 퍼센트 단위다. 표본은 2000년 1월부터 2020년 6월까지 유가증권시장과 코스닥시장에 상장된 보통주 중에서 주당 가격이 500 원보다 큰 주식이다. ${ }^{* * *},{ }^{* *}$, ${ }^{*}$ 는 각각 $1 \%, 5 \%, 10 \%$ 유의수준에서 유의함을 표시한다. 괄호 안의 숫자는 Newey and West(1987) $\mathrm{t}$-통계량이다.

패널 A: NPOS_NEG와 CO

\begin{tabular}{|c|c|c|c|c|}
\hline \multirow{2}{*}{\multicolumn{2}{|c|}{$\mathrm{CO}$ 포트폴리오 }} & \multicolumn{3}{|c|}{ NPOS_NEG } \\
\hline & & 1 & 2 & 3 \\
\hline \multirow[t]{4}{*}{ Low } & 1 & 0.454 & 0.760 & 0.909 \\
\hline & 2 & 0.678 & 1.043 & 1.201 \\
\hline & 3 & 0.730 & 1.152 & 1.223 \\
\hline & 4 & 0.930 & 1.258 & 1.389 \\
\hline High & 5 & 1.015 & 1.299 & 1.458 \\
\hline \multirow{2}{*}{\multicolumn{2}{|c|}{ High-Low }} & $0.561^{* * *}$ & $0.539^{* * *}$ & $0.549^{* * *}$ \\
\hline & & $(3.663)$ & $(4.463)$ & $(3.514)$ \\
\hline
\end{tabular}

패널 $\mathrm{B}: \mathrm{ID}$ 와 $\mathrm{CO}$

\begin{tabular}{cccccc}
\hline \multirow{2}{*}{ CO 포트폴리오 } & \multicolumn{5}{c}{$\mathrm{ID}$} \\
\cline { 2 - 6 } & 1 & 2 & 3 & 4 & 5 \\
\hline Low 1 & 0.053 & 0.615 & 0.768 & 0.964 & 0.958 \\
& 0.303 & 0.836 & 0.832 & 1.088 & 1.211 \\
& 0.620 & 0.868 & 1.179 & 1.228 & 1.271 \\
& 0.927 & 1.093 & 1.251 & 1.253 & 1.289 \\
High 5 & 1.039 & 1.267 & 1.381 & 1.334 & 1.301 \\
High-Low & $0.986^{* * *}$ & $0.652^{* * *}$ & $0.612^{* * * *}$ & $0.370^{* *}$ & $0.343^{* *}$ \\
& $(4.056)$ & $(3.508)$ & $(3.190)$ & $(2.368)$ & $(2.160)$ \\
\hline
\end{tabular}


한국증권학회지 제 50 권 1호 (2021)

유의한 양의 수익률을 가진다. 따라서 과거기간동안 월별 양의 수익률의 달의 수와 음의 수익률을 가지는 달의 수는 $\mathrm{CO}$ 전략에 유의한 영향을 미치지 못한다.

다음으로, 정보의 불연속성과 계속적 과잉반응의 관계를 조사한다. Da et al.(2014)는 정보의 불연속성의 변수(ID)를 정의하여 포트폴리오 구성 기간 중 정보가 연속적인지 불연속적인지 여부를 나타낸다. 위의 연구에 따르면 투자자는 연속적인 정보에 대해 불연속적인 정보보다 주의를 덜 기울인다. 따라서 연속적인 정보가 강한 수익률 지속을 유도한다. $\mathrm{ID}$ 는 일별 수익률의 부호에 따라 식 (7)과 같이 도출된다.

$$
I D_{i, t}=\operatorname{sng}(\text { PRET }) \times(\% \text { neg }-\% \text { pos })
$$

$I D_{i, t}$ 는 $t$ 월의 $i$ 번째 주식의 정보의 불연속성 변수이다. PRET는 $t-12$ 월부터 $t-2$ 월의 일별 누적수익률이다. $\operatorname{sng}(P R E T)$ 는 과거수익률의 부호로 $P R E T>0$ 이면 1 을, $P R E T<0$ 이면 -1 을 부여한다. \%os 는 과거기간동안 양의 수익률을 가지는 날의 비율이고, \%neg는 과거기간동안 음의 수익률을 가지는 날의 비율이다. 과거기간의 수익률이 여러 날에 걸쳐 누적되면 정보의 연속성이 지속되고, 연속적 정보는 더 강하고 지속성인 수익률을 유도한다. 정보의 불연속성 $(\mathrm{ID})$ 은 정보의 상대적 빈도를 나타낸다. 높은 $\mathrm{ID}$ 는 불연속적인 정보를, 낮은 $\mathrm{ID}$ 는 연속적인 정보를 나타낸다. 우리는 $\mathrm{CO}$ 와 정보의 불연속성 측정치를 기준으로 다변량 포트폴리오를 구성한다.

<표 $5>$ 의 패널 $\mathrm{B}$ 는 정보의 불연속성에 따른 $\mathrm{CO}$ 전략을 나타낸다. 과거 12 개월의 일별 누적수익률로 도출된 $\mathrm{ID}$ 를 기준으로 5 개의 포트폴리오를 나누고, 각 $\mathrm{ID}$ 포트폴리오에 속한 주식을 $\mathrm{CO}$ 에 따라 5 분위수 포트폴리오로 나눈다. 그 결과, ID 그룹에서 $\mathrm{CO}$ 전략의 수익률은 $0.986 \%$, $0.652 \%, 0.612 \%, 0.370 \%, 0.343 \%$ 로 모두 유의한 양의 수익률을 가진다. 특히, ID가 높아짐에 따라 $\mathrm{CO}$ 전략의 수익률이 낮아지는 것을 확인한다. <표 $5>$ 의 패널 $\mathrm{B}$ 에 따르면 정보의 불연속성이 $\mathrm{CO}$ 를 완전히 설명하지 못한다.

우리는 기업특성 변수 뿐 아니라 정보의 불연속성을 통제한 경우에도 $\mathrm{CO}$ 전략이 유의한 양의 수익률을 가짐을 보였다. 더 나아가, Fama-Macbeth 횡단면 분석을 통하여 기업특성변수와 수익률 지속성, 정보의 불연속성, 그리고 포트폴리오 구성기간 동안 양과 음의 월별수익률을 가진 달의 개수의 차이를 동시에 통제한 후에도 $\mathrm{CO}$ 가 주식수익률에 대하여 유의한 양의 예측력을 가지는지 확인한다. $\mathrm{ID}$ 는 일별수익률을 이용한 연속적인 변수이지만, Grinblatt and Moskowitz (2004)의 수익률 지속성은 월별수익률을 이용한 불연속적인 변수이다. Da et al.(2014)은 수익률 지속성과 $\mathrm{ID}$ 의 경제적 의미를 구분하기 위하여 과거 승자와 패자의 관점에서 $\mathrm{ID}$ 를 분류한다. 부호화된 ID는 POS_ID와 NEG_ID로 식 (8)과 같다.

$$
\begin{aligned}
P O S_{-} I D_{i, t} & =\left\{\begin{array}{lll}
\% \text { pos }-\% \text { neg } & \text { if } & r_{t-12, t-1}>0 \\
0 & \text { otherwise }
\end{array}\right. \\
N E G_{-} I D_{i, t} & =\left\{\begin{array}{lll}
\% \text { neg-\%pos } & \text { if } & r_{t-12, t-1}<0 \\
0 & \text { otherwise }
\end{array}\right.
\end{aligned}
$$

$\% p o s$ 는 과거기간 동안 양의 수익률을 가지는 날의 비율이고, \%neg는 과거기간 동안 음의 수익률을 가지는 날의 비율이다. $r_{t-12, t-1}$ 은 $t-12$ 월부터 $t-1$ 월의 누적수익률이다. POS_ID는 
Empirical Investigation of the Relationship between Continuing Overreaction and Stock Returns

과거 12 개월의 일별 누적수익률이 양의 값일 경우, 양의 수익률을 가진 날의 비율에서 음의 수익률을 가진 날의 비율을 뺀 값이다. NEG_ID는 과거 12 개월의 일별 누적수익률이 음의 값일 경우, 음의 수익률을 가진 날의 비율에서 양의 수익률을 가진 날의 비율을 뺀 값이다. 과거기간 동안 양과 음의 수익률을 가진 날의 비율의 차이인 POS_ID와 NEG_ID는 정보의 불연속성을 나타낸다.

우리는 Fama and Macbeth(1973)의 횡단면 회귀분석을 통하여 CO의 예측력을 확인한다. 종속변수는 6개월 보유기간 수익률(buy and hold returns)이며 식 (9)에 따라 횡단면 회귀분석을 진행한다.

$$
\begin{aligned}
& r_{i, t+1, t+6}=\lambda_{0}+\lambda_{1, t} C O_{i, t}+\lambda_{2, t} P R E T_{i, t}+\lambda_{3, t} P O S_{-} I D_{i, t}+\lambda_{4, t} N E G_{-} I D_{i, t} \\
& +\lambda_{5, t} P O S_{-} R C_{i, t}+\lambda_{6, t} N E G_{-} R C_{i, t}+\lambda_{7, t} N P O S_{-} N E G_{i, t}+\lambda_{8, t} C G O_{i, t} \\
& +\lambda_{9, t} B E T A_{i, t}+\lambda_{10, t} S I Z E_{i, t}+\lambda_{11, t} B E M E_{i, t}+\lambda_{12, t} R E V_{i, t} \\
& +\lambda_{13, t} I L L I Q_{i, t}+\lambda_{14, t} I V O L_{i, t}+\lambda_{15, t} T_{U R N_{i, t}}+\epsilon_{i, t+1, t+6},
\end{aligned}
$$

$r_{i, t+1, t+6}$ 는 $i$ 번째 주식의 $t+1$ 월부터 $t+6$ 월의 6 개월 수익률이고, $C O_{i, t}$ 는 $\mathrm{CO}$ 변수이다. $P R E T_{i, t}$ 는 지난 $t-12$ 월부터 $t-2$ 월의 누적수익률이며, $P O S_{-} I D_{i, t}$ 와 $N E G_{-} I D_{i, t}$ 는 정보의 불연속성 변수이다. POS_RC $C_{i, t}$ 와 $N E G_{-} R C_{i, t}$ 는 수익률 지속성 가변수이다. $N P O S_{-} N E G_{i, t}$ 는 양의 수익률을 가지는 달의 개수에서 음의 수익률을 가지는 달의 개수를 뺀 값이다. $C G O_{i, t}$ 는 미실현 자본 이익이다. $B E T A_{i, t}$ 는 $t$ 월의 시장베타이다. $S I Z E_{i, t}$ 는 $t$ 월의 기업규모이고, $B E M E_{i, t}$ 는 $t$ 월의 장부가치 대 시장가치이며, $R E V_{i, t}$ 는 단기수익률반전이다. $I L L I Q_{i, t}$ 는 Amihud(2002)에 따른 유동성 변수이며, $I V O L_{i, t}$ 은 $t$ 월의 고유변동성이고, $T U R N_{i, t}$ 는 과거 12 개월의 평균 월별거래량 회전률이다.

<표 6>은 회귀계수의 시계열 평균이며, 괄호안의 값은 Newey and West(1987)의 t-통계량 이다. 모형 1 은 $\mathrm{CO}$ 과 횡단면적 주식수익률 간의 관계를 나타낸다. 모형 1 에 따르면 $\mathrm{CO}$ 는 횡단면적 주식수익률에 유의한 양의 예측력을 가진다. CO 회귀계수의 평균은 0.042 이고, $\mathrm{t}$-통계량은 3.739 이다. 모형 2 는 $\mathrm{CO}$ 와 과거수익률 $\mathrm{PRET}$ )를 회귀분석에 추가한 결과이다. PRET는 주식수익률과 유의한 음의 관계가 있는 반면, $\mathrm{CO}$ 의 회귀계수는 0.052 이고 t-통계량은 4.975로 모형 1 에 비하여 상승했다. 과거수익률을 고려한 후에도 횡단면적 수익률에 대한 $\mathrm{CO}$ 의 예측력이 유지된다. 모형 3 과 모형 4 는 정보의 불연속성과 수익률 지속성 변수를 고려한 경우이다. 두 경우에서 $\mathrm{CO}$ 는 횡단면적 주식수익률에 대하여 여전히 유의한 양의 회귀계수를 가진다. 더 나아가, 기업특성 변수를 회귀모형에 추가한 모형 5와 모형 6에서도 $\mathrm{CO}$ 는 주식수익률에 유의한 양의 예측력을 가진다. 우리는 여러 가지 변수를 통제하여도 주식수익률에 대한 계속적 과잉반응의 예측력이 유지됨을 재확인한다.

종합하면, 본 절에서는 기존의 연구에 따라 수익률 지속성과 정보의 불연속성이 기대수익률에 미치는 영향을 확인한다. 포트폴리오 분석을 통해 정보의 불연속성과 포트폴리오 구성기간 동안 양과 음의 월별수익률을 가진 달의 개수의 차이를 통제한 후 $\mathrm{CO}$ 와 주식수익률간의 관계를 
한국증권학회지 제 50 권 1호 (2021)

나타낸다. 추가적인 변수를 고려한 후에도 $\mathrm{CO}$ 는 주식수익률과 유의한 양의 관계를 가진다. 더 나아가, Fama-Macbeth 횡단면 분석을 통해 수익률 지속성과 추가적 요인을 동시에 고려하여

〈표 6〉Fama-Macbeth 횡단면 분석

이 표는 기업수준에서 Fama-Macbeth 횡단면 분석을 나타낸다. 6개월 보유수익률을 종속변수로 하고, 계속적 과잉반응(CO), 과거수익률(PRET), 정보의 불연속성(POS_ID/NEG_ID), 수익률 지속성(POS_RC NEG_RC), 양과 음의 수익률을 가진 개월의 차이(NPOS_NEG), 미실현 자본이익(CGO), 그리고 기업특성 요인을 독립변수로 한 횡단면 분석이다. 각 열은 횡단면 회귀분석 회귀계수의 시계열 평균과 조정된 $R^{2}$ 를 나타낸다. 표본은 2000년 1월부터 2020년 6월까지 유가증권시장과 코스닥시장에 상장된 보통주 중에서 주당 가격이 500 원보다 큰 주식이다. ${ }^{* * *},{ }^{* *}$, *는 각각 $1 \%, 5 \%, 10 \%$ 유의수준에서 유의함을 표시한다. 괄호 안의 숫자는 Newey and West(1987) t-통계량이다.

\begin{tabular}{|c|c|c|c|c|c|c|c|}
\hline & \multicolumn{7}{|c|}{ 모형 } \\
\hline & 1 & 2 & 3 & 4 & 5 & 6 & 7 \\
\hline \multirow[t]{2}{*}{$\mathrm{CO}$} & $0.042^{* * *}$ & $0.052^{* * *}$ & $0.043^{* * *}$ & $0.051^{* * *}$ & $0.043^{* * *}$ & $0.031^{* * *}$ & $0.030^{\text {**** }}$ \\
\hline & (3.739) & $(4.975)$ & $(4.112)$ & $(4.725)$ & (3.983) & $(2.724)$ & $(2.626)$ \\
\hline \multirow[t]{2}{*}{ PRET } & & $-0.018^{* *}$ & $-0.027^{* * *}$ & $-0.018^{* *}$ & -0.001 & -0.006 & -0.005 \\
\hline & & $(-2.247)$ & $(-3.185)$ & $(-2.467)$ & $(-0.152)$ & $(-0.743)$ & $(-0.691)$ \\
\hline \multirow[t]{2}{*}{ POS_ID } & & & 0.059 & & $0.115^{*}$ & 0.096 & 0.102 \\
\hline & & & $(0.791)$ & & (1.749) & $(1.481)$ & $(1.534)$ \\
\hline \multirow[t]{2}{*}{ NEG_ID } & & & $-0.294^{* * *}$ & & $-0.228^{* * *}$ & $-0.192^{* * *}$ & $-0.183^{* * *}$ \\
\hline & & & $(-3.966)$ & & $(-3.871)$ & $(-3.379)$ & $(-3.110)$ \\
\hline \multirow[t]{2}{*}{ POS_RC } & & & & 0.619 & 0.865 & -0.379 & -0.364 \\
\hline & & & & $(0.454)$ & $(0.743)$ & $(-0.357)$ & $(-0.340)$ \\
\hline \multirow[t]{2}{*}{ NEG_RC } & & & & $-2.256^{* *}$ & -0.582 & 0.580 & 0.900 \\
\hline & & & & $(-1.973)$ & $(-0.610)$ & $(0.590)$ & $(0.972)$ \\
\hline \multirow[t]{2}{*}{ NPOS_NEG } & & & & & & $0.347^{* * *}$ & $0.358^{* * *}$ \\
\hline & & & & & & (2.918) & $(2.936)$ \\
\hline \multirow[t]{2}{*}{ CGO } & & & & & & & 0.068 \\
\hline & & & & & & & $(0.067)$ \\
\hline \multirow[t]{2}{*}{ BETA } & & & & & 0.712 & 0.729 & 0.750 \\
\hline & & & & & (1.208) & $(1.241)$ & (1.318) \\
\hline \multirow[t]{2}{*}{ SIZE } & & & & & $-2.524^{* * *}$ & $-2.579^{* * *}$ & $-2.557^{* * * *}$ \\
\hline & & & & & $(-6.463)$ & $(-6.589)$ & $(-6.583)$ \\
\hline \multirow[t]{2}{*}{ BEME } & & & & & 0.719 & 0.729 & 0.726 \\
\hline & & & & & (1.302) & (1.318) & (1.354) \\
\hline \multirow[t]{2}{*}{ REV } & & & & & -0.019 & -0.007 & -0.007 \\
\hline & & & & & $(-1.156)$ & $(-0.369)$ & $(-0.422)$ \\
\hline \multirow[t]{2}{*}{ ILLIQ } & & & & & $0.563^{*}$ & $0.561^{*}$ & $0.575^{*}$ \\
\hline & & & & & $(1.692)$ & $(1.690)$ & (1.739) \\
\hline \multirow[t]{2}{*}{ IVOL } & & & & & $-1.394^{* * *}$ & $-1.374^{* * *}$ & $-1.369^{* * * *}$ \\
\hline & & & & & $(-5.537)$ & $(-5.462)$ & $(-5.485)$ \\
\hline \multirow[t]{2}{*}{ TURN } & & & & & $-5.196^{* * *}$ & $-5.210^{* * *}$ & $-5.085^{* * *}$ \\
\hline & & & & & $(-6.121)$ & $(-6.181)$ & $(-6.053)$ \\
\hline Adj. $R^{2}$ & 0.004 & 0.008 & 0.012 & 0.008 & 0.057 & 0.058 & 0.060 \\
\hline
\end{tabular}


Empirical Investigation of the Relationship between Continuing Overreaction and Stock Returns

$\mathrm{CO}$ 과 횡단면적 주식수익률 간의 관계를 확인한다. 우리는 계속적 과잉반응이 주식수익률에 미치는 영향은 수익률 지속성과 정보의 불연속성에 의한 현상이 아님을 재확인한다. 또한, $\mathrm{CO}$ 는 횡단면적 주식수익률에 유의한 양의 예측력을 가짐을 제시한다.

\section{5 미실현 자본이익과 계속적 과잉반응}

Grinblatt and Han(2005)에 따르면 디스포지션 효과에 의한 거래로 인해 미실현 자본이익 (unrealized capital gains)이 증가할수록 주가는 저평가된다. 주가가 저평가되면 주식수익률은 증가하는 현상이 발생한다. 이와 반대로 미실현 자본손실이 증가할수록 주가는 고평가되어 주식수익률은 낮아진다. Grinblatt and Han(2005)는 미실현 자본이익의 대용변수가 모멘텀 전략의 수익성을 창출하는 핵심변수라고 주장하며 미실현 자본이익을 통제한 후 과거수익률이 횡단면적으로 수익률을 예측하지 못함을 보인다. Oh and Hahn(2012)은 Grinblatt and $\operatorname{Han}(2005)$ 에 따라 유가증권시장에서 미실현 자본이익과 주식수익률은 양의 관계를 확인한다. 그 결과, 국내주식시장에서 미실현 자본이익이 모멘텀 현상을 설명함을 보인다. Oh and $\operatorname{Hahn}$ (2013)에 따르면 국내 주식시장에서 미실현 자본이익에 따른 현상은 미실현 자본이익의 부호에 따라 비대칭적으로 발생하며 미처분 이익이 양수인 경우에만 뚜렷한 현상이 나타난다.

제 4장 제 2절에서 CO전략은 모멘텀 전략의 수익률로 기준조정 한 후에도 여전히 유의한 양의 수익률을 가진다. Oh and $\operatorname{Hahn}(2012)$ 에 따르면 국내 주식시장에서 미실현 자본이익이 모멘텀 현상을 설명하고, 미실현 자본이익과 주식수익률간의 유의한 양의 관계가 존재한다. 따라서 본 절에서는 모멘텀 현상의 핵심변수인 미실현 자본이익과 계속적 과잉반응간의 관계를 살펴본다. <표 7>은 다변량 포트폴리오 분석을 통하여 미실현 자본이익을 통제한 후 계속적 과잉반응이 유지되는지 여부를 제시한다.

$$
\begin{aligned}
& g_{t-1}=1-R_{t-1} / P_{t-2} \\
& R_{t-1}=\frac{1}{k} \sum_{n=1}^{260}\left(V_{t-1-n} \prod_{\tau=1}^{n-1}\left[1-V_{t-1-n+\tau}\right]\right) P_{t-1-n}
\end{aligned}
$$

미실현 자본이익은 식 (10)과 같다. Grinblatt and $\operatorname{Han}(2005)$ 은 주별 주식데이터를 이용하여 미실현 자본이익을 계산한다. 본 연구에서는 과거 5 년의 주별 주식데이터를 이용하여 도출하되 An et al.(2019)에서 제시한 바와 같이 매 월 마지막 주의 미실현 자본이익을 매 월 미실현 자본이익으로 나타낸다. $g$ 는 미실현 자본이익이며, $P$ 는 주식가격이다. $R$ 은 기준가격이며, $V$ 는 주별 회전율(주별 거래량/주별 발행주식수)의 평균이다. $k$ 는 과거 주식가격의 가중치로 합이 1 이 되는 상수이다.

$<$ 표 7>의 패널 $\mathrm{A}$ 는 미실현 자본이익을 통제한 후 $\mathrm{CO}$ 전략의 수익성을 나타낸다. 매월 미실현 자본이익을 기준으로 5 분위수 포트폴리오를 나누고 각 미실현 자본이익 포트폴리오에 속한 주식을 $\mathrm{CO}$ 에 따라 5 분위수 포트폴리오를 구성한다. 미실현 자본이익 포트폴리오 1(5)은 미실현 자본이익이 가장 낮은(높은) 포트폴리오에 속한 $\mathrm{CO}$ 포트폴리오를 의미한다. 그 결과 $\mathrm{CO}$ 포트폴리오의 수익률은 모든 미실현 자본이익 포트폴리오에서 단조롭게 증가하는 패턴을 가진다. 
한국증권학회지 제 50 권 1호 (2021)

미실현 자본이익을 기준으로 한 포트폴리오에서 CO전략의 수익률 각각 $0.870 \%, 0.840 \%, 0.587 \%$, 0.346\%, 0.683\%이며 포트폴리오 4를 제외하면 모두 통계적으로 유의하다. 매 월 포트폴리오 4 에 속한 주식의 미실현 자본이익 평균한 결과 0.115 로 0에 가까운 양수라는 것을 확인한다. 포트폴리오 3 과 5 의 미실현 자본이익의 평균과 비교한 결과 0에 가까운 양수일 경우 CO전략의 유의성이 하락한다. 우리는 미실현 자본이익의 비대칭적인 효과를 면밀히 확인하기 위하여 양의 미실현 자본이익과 음의 미실현 자본이익에 따른 $\mathrm{CO}$ 전략을 분석한다.

\section{〈표 7〉미실현 자본이익과 CO전략}

이 표는 미실현 자본이익을 제어한 후 $\mathrm{CO}$ 전략의 수익성을 나타낸다. 패널 $\mathrm{A}$ 는 매월 말 식 (10)으로 도출된 미실현 자본이익을 기준으로 5 분위수 포트폴리오를 구성하고, 각 포트폴리오에 속한 주식을 $\mathrm{CO}$ 에 따라 5 분위수 포트폴리오로 나누어 미실현 자본이익을 통제한 $\mathrm{CO}$ 전략의 수익성을 나타낸다. 패널 $\mathrm{B}$ 는 비대칭적 미실현 자본이익에 따른 CO전략을 확인한다. 매월 말 양의 미실현 자본이익(POS_G)과 음의 미실현 자본이익(NEG_G)을 가진 주식을 나누고, 각 그룹에서 중앙값을 기준으로 2 분위수 포트폴리오를 구성하여 각 포트폴리오에 속한 주식을 다시 $\mathrm{CO}$ 를 기준으로 5분위수 포트폴리오를 구성한다. 보유기간은 6 개월 $(K=6)$ 이고, 수익률은 퍼센트 단위다. 표본은 2000년 1월부터 2020년 6월까지 유가증권시장과 코스닥시장에 상장된 보통주 중에서 주당 가격이 500 원보다 큰 주식이다. ${ }^{* * *},{ }^{* *},{ }^{*}$ 는 각각 1\%, 5\%, 10\% 유의수준에서 유의함을 표시한다. 괄호 안의 숫자는 Newey and West(1987) t-통계량이다.

패널 $\mathrm{A}$ : 미실현 자본이익과 $\mathrm{CO}$

\begin{tabular}{cccccc}
\hline \multirow{2}{*}{ CO 포트폴리오 } & \multicolumn{5}{c}{ 미실현 자본이익 } \\
\cline { 2 - 6 } & 1 & 2 & 3 & 4 & 5 \\
\hline Low 1 & 0.755 & 0.895 & 0.899 & 0.971 & 0.862 \\
2 & 0.970 & 1.158 & 1.201 & 0.970 & 1.030 \\
3 & 1.087 & 1.298 & 1.305 & 1.267 & 1.208 \\
4 & 1.415 & 1.313 & 1.550 & 1.514 & 1.166 \\
High 5 & 1.624 & 1.736 & 1.486 & 1.318 & 1.545 \\
High-Low & $0.870^{* * *}$ & $0.840^{* * *}$ & $0.587^{* * *}$ & 0.346 & $0.683^{* * *}$ \\
& $(3.225)$ & $(4.301)$ & $(3.223)$ & $(1.633)$ & $(3.483)$ \\
\hline
\end{tabular}

패널 $\mathrm{B}:$ 비대칭적 미실현 자본이익과 $\mathrm{CO}$

\begin{tabular}{cccccc}
\hline \multirow{2}{*}{ CO 포트폴리오 } & \multicolumn{3}{c}{ NEG_G } & & \multicolumn{2}{c}{ POS_G } \\
\cline { 2 - 3 } \cline { 5 - 6 } & 1 & 2 & & 1 & 2 \\
\hline Low 1 & 0.729 & 1.738 & & 0.896 & 0.811 \\
2 & 1.055 & 1.150 & & 1.004 & 1.008 \\
3 & 1.105 & 1.302 & & 1.127 & 1.192 \\
4 & 1.311 & 1.729 & & 1.165 & 1.123 \\
High 5 & 1.597 & $0.991^{* * *}$ & & 0.269 & 1.588 \\
High-Low & $0.868^{* * *}$ & $(5.105)$ & & $(1.300)$ & $0.778^{* * * *}$ \\
& $(3.657)$ & & & & $(3.756)$ \\
\hline
\end{tabular}

Oh and Hahn(2013)에 따르면 국내 주식시장에서 미실현 자본이익의 부호에 따른 주식 수익률에 대해 비대칭적 효과가 존재한다. 미실현 자본이익이 음수일 경우 주식수익률에 대한 영향이 미미하다. 하지만, 미실현 자본이익이 양수일 경우 미실현 자본이익이 증가할수록 주가가 
Empirical Investigation of the Relationship between Continuing Overreaction and Stock Returns

저평가되고 기대수익률이 증가하는 현상이 관측된다. 음의 미실현 자본이익의 영향이 약하다면, 음의 미실현 자본이익을 통제한 경우에 양의 미실현 자본이익을 통제한 것 보다 높은 수익률을 가질 것이라고 예상할 수 있다. 우리는 미실현 자본이익의 비대칭적 효과를 통제하기 위해 다음과 같이 포트폴리오를 구성한다. 먼저, 양의(음의) 미실현 자본이익을 가지는 주식을 POS_G(NEG_G)로 분류한다. POS_G(NEG_G)를 중앙값 기준으로 하위포트폴리오와 상위 포트폴리오로 나누고 각각 포트폴리오 1 과 2 를 부여하여 총 4 개의 그룹을 구성한다. 4 개의 포트폴리오에서 다시 $\mathrm{CO}$ 를 기준으로 5 분위수 포트폴리오를 구성한 결과를 나타낸다. <표 $7>$ 의 패널 B에 따르면, 각 포트폴리오에서는 CO전략의 수익률이 0.868\%, 0.991\%, 0.269\%, 0.778\%이다. POS_G의 포트폴리오 1 을 제외하면 모두 유의한 양의 수익률이다. 미실현 자본이익이 음수일 경우 모두 포트폴리오 수익률은 단조롭게 증가하는 패턴을 가지지만 POS_G의 포트폴리오 1 에서는 $\mathrm{CO}$ 가 증가함에 따라 포트폴리오 수익률이 증가하는 패턴을 가지지 않는다. 패널 $\mathrm{A}$ 와 유사하게 POS_G의 포트폴리오 1에 속한 주식의 평균 미실현 자본이익은 0.097로 0에 가까운 양수이다. 즉, Oh and Hahn(2013)에서 언급한 바와 같이 음의 미실현 자본이익을 가질 경우 양의 미실현 이익을 가질 때보다 무비용 포트폴리오의 수익률이 높다. 우리는 모멘텀 전략의 수익률에 핵심요소인 미실현 자본이익이 $\mathrm{CO}$ 를 충분히 설명하지 못하지만, 미실현 자본이익이 0에 가까운 양수일 경우는 예외가 된다는 사실을 확인한다. 따라서 Oh and Hahn(2013)과 유사하게 한국 주식시장에서 미실현 자본이익이 0에 가까운 양의 값일 때 미실현 자본이익의 비대칭적 효과가 나타난다. 하지만, <표 6>의 Fama-Macbeth 횡단면분석에서 미실현 자본이익을 통제한 모형 7의 경우, $\mathrm{CO}$ 는 횡단면적 주식수익률에 대하여 유의한 양의 예측력을 가지지만 미실현 자본이익은 주식수익률에 유의한 영향을 미치지 못한다.

종합하면, Grinblatt and $\operatorname{Han}(2005)$ 에 의해 모멘텀 현상의 수익성을 창출하는 핵심요인인 미실현 자본이익은 $\mathrm{CO}$ 전략을 충분히 설명하지 못한다. 비대칭적 미실현 자본이익의 효과를 확인한 결과, 음의 미실현 자본이익에서 $\mathrm{CO}$ 전략은 상대적으로 더 높은 수익률을 가진다. 따라서 미실현 자본이익을 통제한 후 계속적 과잉반응은 주식수익률에 대체적으로 유의한 양의 영향을 준다.

\section{6 잔여 계속적 과잉반응(residual continuing overreaction)과 주식수익률}

Blitz et al.(2011)은 잔여모멘텀(residual momentum) 전략과 모멘텀 전략을 비교 분석한다. 잔여모멘텀은 기존의 모멘텀보다 크고 유의한 양의 수익률을 가지며 금융위기 기간 동안 일관된 성과를 가진다. 또한, 잔여모멘텀은 1 월 효과(January effect) 같은 계절적 패턴에 관여 받지 않는다. Blizt et al.(2020)은 Blitz et al.(2011)과 Gutierrez and Prinsky(2007)에 따라 고유 모멘텀(idiosyncratic momentum)을 도출한다. 고유모멘텀은 전통적 모멘텀 전략에 의해 설명되지 않는 현상이며, 모멘텀의 이상수익률 현상을 설명하는 요인으로 통제한 후에도 주식수익률을 횡단면적으로 설명한다. 또한, 시장상태와 시장동태(market dynamics)와 관련된 투자자의 과신과 과잉반응은 고유모멘텀의 수익률을 설명할 수 없다고 주장한다. 
본 절에서 잔여수익률을 이용하여 계속적 과잉반응을 추정하고, 주식수익률과 잔여 계속적 과잉반응(residual continuing overreaction, $\mathrm{RCO}$ )의 관계를 확인한다. 잔여수익률(residual return)은 Blitz et al.(2011)과 Gutierrez and Prinsky(2007)에 기반을 둔 Blizt et al.(2020)에 따라 도출된다. 과거 36개월 주식데이터와 식 (3)을 이용하여 각 회귀계수를 구하고, 식 (11)에 따라 잔여수익률 $\left(\epsilon_{i, t}\right)$ 을 도출한다.

$$
\epsilon_{i, t}=R_{i, t}-r_{f, t}-\hat{\alpha}_{i}+\hat{\beta}_{1, i}\left(R_{m, t}-r_{f, t}\right)
$$

우리는 식 (1)에서 사용된 수익률을 잔여수익률로 변경하여 식 (12)에 따라 부호화된 거래량 $(R S V)$ 을 도출한다. 잔여 계속적 과잉반응 $(R C O)$ 은 식 (12)에서 도출된 $R S V$ 을 식 (13)에 대입하여 계산한다.

$$
R S V_{i, t}=\left\{\begin{array}{cl}
V O L_{i, t} & \text { if } \epsilon_{i, t}>0 \\
0 & \text { if } \epsilon_{i, t}=0 \\
-V O L_{i, t} & \text { if } \epsilon_{i, t}<0
\end{array}\right.
$$

$V O L_{i, t}$ 는 $t$ 월의 $i$ 번째 주식의 월별거래대금이고, 각 달의 일별 주식거래량에 종가를 곱한 값의 합으로 정의한다. $\epsilon_{i, t}$ 는 $t$ 월의 $i$ 번째 잔여수익률이다. 잔여 계속적 과잉반응 $(R C O)$ 은 식 (13)에 따라 도출한다.

$$
R C O_{i, t}=\frac{\sum_{j=1}^{J}\left(w_{j} \times R S V_{i, t-j}\right)}{\operatorname{mean}\left(V O L_{i, t-J}, \ldots, V O L_{i, t-1}\right)}
$$

$R S V_{i, t}$ 는 $t$ 월의 $i$ 번째 주식의 부호화된 거래량이다. $R C O_{i, t}$ 는 잔여 계속적 과잉반응을 나타내는 측정치로 사용한다.

<표 8>은 RCO와 주식수익률간의 관계를 나타낸다. <표 8>에 따르면 RCO는 주식수익률과 양의 관계에 있다. 음의 $\mathrm{RCO}$ 를 가지는 포트폴리오(Low 1)는 다른 포트폴리오에 비하여 상대적으로 낮은 수익률을 가지고, 양의 $\mathrm{RCO}$ 를 가지는 포트폴리오(High 10)는 상대적으로 높은 수익률을 가진다. 보유기간이 6 개월, 9 개월, 12 월일 경우 무비용 포트폴리오의 수익률은 $0.562 \%, 0.598 \%, 0.459 \%$ 로 유의한 양의 값이며, RCO가 증가함에 따라 주식수익률이 단조롭게 증가하는 패턴을 가진다. 즉, 잔여 계속적 과잉반응은 주식수익률과 유의한 양의 관계에 있으며 연간 $5 \%$ 에서 $7 \%$ 사이의 수익률을 가진다. 이는 여전히 유의한 양의 수익률 이지만, <표 $2>$ 의 $\mathrm{CO}$ 전략에 비하여 낮은 평균수익률을 가진다.

<그림 3>은 CO전략과 RCO전략의 누적수익률을 나타낸다. 2004년에는 두 전략이 비슷한 수준의 수익률을 가진다. 반면, 2005년에 CO전략이 음의 수익률을 가지면서 두 전략의 수익률에 차이가 발생하고 RCO전략이 더 높은 수익률을 가진다. 2010년대에 들어가면서 CO전략의 수익률이 더 높아지고 2020 년까지 이어지는 것을 확인한다. 결과적으로 $\mathrm{CO}$ 전략의 수익률은 
Empirical Investigation of the Relationship between Continuing Overreaction and Stock Returns

$2.1 \%$ 수준을 유지하고, $\mathrm{RCO}$ 전략은 $1.9 \%$ 정도의 수익률을 유지한다. 이를 통하여, 기존의 결과와 유사하게 국내 주식시장에서 $\mathrm{CO}$ 전략과 $\mathrm{RCO}$ 전략 모두 유의한 양의 수익률을 가짐을 확인한다.

〈표 8〉RCO 기반 포트폴리오 수익률

매월 말 잔여수익률로 도출된 $\mathrm{RCO}$ 를 기준으로 구성한 10 개 포트폴리오의 보유수익률이다. 포트폴리오 구성기간은 12 개월 $(J=12)$ 이며, 각 포트폴리오를 6 개월, 9 개월, 그리고 12 개월 보유한 포트폴리오 수익률이다. CAPM은 시장요인으로 위험을 조정한 수익률이다. 보유기간은 각각 6 개월 $(K=6), 9$ 개월 $(K=9), 12$ 개월 $(K=12)$ 이다. 수익률은 퍼센트 단위다. 표본은 2000년 1월부터 2020년 6 월까지 유가증권 시장과 코스닥시장에 상장된 보통주 중에서 주당 가격이 500 원보다 큰 주식이다. ${ }^{* * *},{ }^{* *},{ }^{*}$ 는 각각 $1 \%$, $5 \%, 10 \%$ 유의수준에서 유의함을 표시한다. 괄호 안의 숫자는 Newey and West(1987) t-통계량이다.

\begin{tabular}{cccc}
\hline \multirow{2}{*}{$\mathrm{RCO}$ 포트폴리오 } & $\mathrm{J}=12$ & \\
\cline { 2 - 4 } & $\mathrm{K}=6$ & $\mathrm{~K}=9$ & $\mathrm{~K}=12$ \\
\hline Low 1 & 0.918 & 0.902 & 0.919 \\
2 & 1.016 & 1.033 & 1.079 \\
3 & 1.113 & 1.128 & 1.122 \\
4 & 1.121 & 1.160 & 1.161 \\
5 & 1.252 & 1.237 & 1.237 \\
6 & 1.342 & 1.293 & 1.261 \\
7 & 1.341 & 1.326 & 1.295 \\
8 & 1.412 & 1.391 & 1.340 \\
9 & 1.487 & 1.449 & 1.355 \\
10 & 1.479 & 1.500 & 1.379 \\
High-Low & $0.562^{* * *}$ & $0.598^{* * *}$ & $0.459^{* * *}$ \\
& $(3.223)$ & $(3.722)$ & $(3.305)$ \\
\hline
\end{tabular}

\section{〈그림 3〉 $\mathrm{CO}$ 와 RCO전략의 누적수익률}

이 그림은 $\mathrm{CO}$ 와 $\mathrm{RCO}$ 가 가장 높은 포트폴리오의 수익률에서 가장 낮은 포트폴리오의 수익률을 뺀 무비용 포트폴리오의 누적수익률을 나타낸다. $\mathrm{CO}$ 는 과거 12 개월의 수익률을 기준으로 도출되며, $\mathrm{RCO}$ 는 $\mathrm{CAPM}$ 모형을 사용하여 추정된 잔여수익률을 기준으로 정의된다. 수익률은 퍼센트 단위다. 표본은 2000년 1 월부터 2020년 6월까지 유가증권시장과 코스닥시장에 상장된 보통주 중에서 주당 가격이 500 원보다 큰 주식이다.

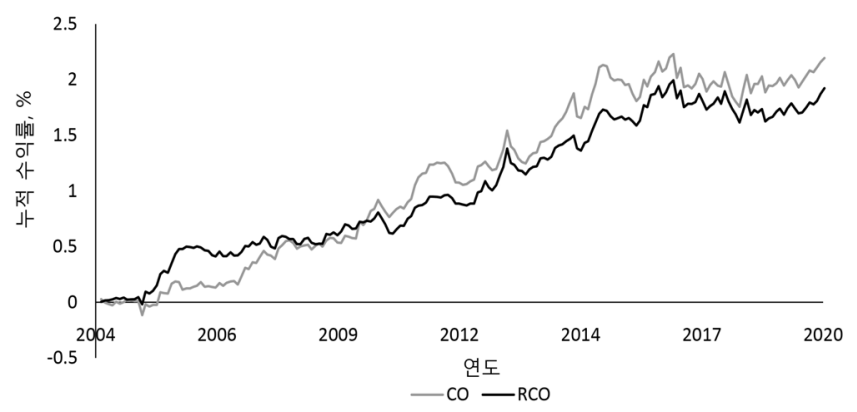

우리는 잔여 계속적 과잉반응 $(\mathrm{RCO})$ 과 잔여모멘텀 전략의 수익성을 비교하기 위하여 제 4 장 제 2 절과 같이 기준조정 수익률을 확인한다. 기존의 연구에 의하면, 미국 주식시장에서 
한국증권학회지 제 50 권 1 호 (2021)

잔여모멘텀이 수익률 모멘텀전략에 비하여 2 배가량 높은 수익률을 가진다. 우리는 국내 주식시장에서 잔여모멘텀의 영향을 확인하고, 잔여 계속적 과잉반응의 영향에 관여하는지 여부를 확인한다. 잔여모멘텀은 Blitz et al.(2011)에 따라 $t-12$ 월부터 $t-2$ 월의 잔여수익률을 표준화한 값이다.

<표 9>는 RCO와 잔여모멘텀 포트폴리오 수익률과 기준조정 수익률이다. RCO 포트폴리오는 식 (13)에 따라 도출된 RCO를 기준으로 10 분위수 포트폴리오를 구성한다. RCO 포트폴리오의 잔여모멘텀 조정수익률은 매월 말 $\mathrm{RCO}$ 를 기준으로 구성된 10 개 포트폴리오의 수익률에서 그 주식이 속한 잔여모멘텀 포트폴리오 수익률을 뺀 값이다. 잔여 포트폴리오의 월별수익률은 $0.918 \%$ 에서 $1.479 \%$ 로 단조롭게 증가하는 패턴을 가지며, RCO가 가장 높은 포트폴리오와 가장 낮은 포트폴리오의 차이는 $0.562 \%$ 로 유의한 양의 값이다. 잔여모멘텀 조정수익률은 $-0.172 \%$ 에서 $0.090 \%$ 이며, 차이값은 $0.262 \%$ 로 통계적으로 유의하다. RCO전략은 <표 8>과 <그림 3>에서 나타냈듯이 CO전략에 비하여 낮은 수익률을 가지지만 그 값은 경제적으로나 통계적으로 유의한 양의 값이다. 잔여모멘텀 전략의 수익률은 $0.399 \%$ 로 유의한 양의 값이지만 모멘텀 전략에 비하여 낮은 수익률을 가진다. 하지만, $\mathrm{RCO}$ 조정 수익률에 경우 뚜렷한 패턴이 사라지며 통계적으로 유의하지 않다. 잔여모멘텀 전략은 국내 주식시장에서 수익률 모멘텀 전략에 비하여 우월한 결과를 가지지 못한다. 더 나아가, 잔여모멘텀 전략의 기준조정 수익률은 $\mathrm{RCO}$ 에 의하여 통제되어 그 영향이 사라진다.

\section{〈표 9〉 RCO, 잔여모멘텀의 기준조정 수익률}

이 표는 보유기간이 6 개월 $(K=6)$ 인 $\mathrm{RCO}$ 포트폴리오와 잔여모멘텀 포트폴리오 수익률과 기준조정 수익률 결과다. 잔여모멘텀( $\mathrm{RCO}$ )조정 수익률은 매월 말 $\mathrm{RCO}$ (잔여모멘텀)를 기준으로 구성된 포트폴리오 수익률 에서 그 주식이 속한 잔여모멘텀( $\mathrm{RCO}$ ) 10 분위수 포트폴리오의 수익률을 감한 값이다. 보유기간은 6 개월 $(K=6)$ 이고, 수익률은 퍼센트 단위다. 표본은 2000년 1월부터 2020년 6월까지 유가증권시장과 코스닥시장에 상장된 보통주 중에서 주당 가격이 500 원보다 큰 주식이다. *****, *는 각각 $1 \%, 5 \%, 10 \%$ 유의수준에서 유의함을 표시한다. 괄호 안의 숫자는 Newey and West(1987) t-통계량이다.

\begin{tabular}{|c|c|c|c|c|c|c|c|}
\hline \multicolumn{2}{|c|}{$\begin{array}{c}\mathrm{RCO} \\
\text { 포트폴리오 }\end{array}$} & 월별수익률 & $\begin{array}{l}\text { 잔여모멘텀 } \\
\text { 조정수익률 }\end{array}$ & \multicolumn{2}{|c|}{$\begin{array}{l}\text { 잔여모멘텀 } \\
\text { 포트폴리오 }\end{array}$} & 월별수익률 & \multirow[t]{2}{*}{$\begin{array}{c}\mathrm{RCO} \\
\text { 조정수익률 }\end{array}$} \\
\hline \multirow[t]{9}{*}{ Low } & 1 & 0.918 & -0.172 & \multirow[t]{9}{*}{ Low } & 1 & 0.844 & \\
\hline & 2 & 1.016 & -0.114 & & 2 & 0.970 & -0.100 \\
\hline & 3 & 1.113 & -0.061 & & 3 & 1.096 & -0.001 \\
\hline & 4 & 1.121 & -0.088 & & 4 & 1.176 & -0.007 \\
\hline & 5 & 1.252 & 0.018 & & 5 & 1.243 & 0.057 \\
\hline & 6 & 1.342 & 0.076 & & 6 & 1.323 & 0.076 \\
\hline & 7 & 1.341 & 0.052 & & 7 & 1.287 & 0.065 \\
\hline & 8 & 1.412 & 0.096 & & 8 & 1.287 & 0.025 \\
\hline & 9 & 1.487 & 0.137 & & 9 & 1.251 & -0.061 \\
\hline \multirow{3}{*}{\multicolumn{2}{|c|}{$\begin{array}{l}\text { High } 10 \\
\text { High-Low }\end{array}$}} & 1.479 & 0.090 & \multirow{3}{*}{\multicolumn{2}{|c|}{$\begin{array}{l}\text { High } 10 \\
\text { High-Low }\end{array}$}} & 1.423 & 0.022 \\
\hline & & $0.562^{* * *}$ & $0.262^{* *}$ & & & $0.399^{* * * *}$ & 0.177 \\
\hline & & (3.223) & $(2.418)$ & & & $(2.946)$ & (1.137) \\
\hline
\end{tabular}


Empirical Investigation of the Relationship between Continuing Overreaction and Stock Returns

요약하면, 본 절에서는 잔여모멘텀의 개념을 계속적 과잉반응에 적용하여 잔여 계속적 과잉반응 $(\mathrm{RCO})$ 의 존재를 확인한다. $\mathrm{RCO}$ 는 주식수익률과 유의한 양의 관계를 가지지만 그 값이 $\mathrm{CO}$ 전략보다는 낮은 수익률을 가진다. 누적수익률의 경우 $\mathrm{CO}$ 전략이 $\mathrm{RCO}$ 전략보다 높은 수익률을 가진다. 잔여수익률을 이용한 $\mathrm{RCO}$ 전략도 양의 수익률을 가지지만, $\mathrm{CO}$ 전략의 수익률이 더 높다. 따라서 잔여모멘텀 전략에서 더 높은 수익성을 얻었던 기존의 연구와는 달리, 계속적 과잉반응에서는 잔여수익률을 사용한 전략이 기존에 비하여 더 낮은 성과를 가진다. RCO 포트폴리오의 잔여모멘텀 조정수익률은 단조롭게 상승하는 패턴을 가지며, 유의한 양의 수익률을 가진다. 이는 잔여수익률에 비하여 주식수익률에 기반을 둔 투자자의 계속적 과잉반응이 미래수익률에 더 강한 양의 영향을 미친다는 사실을 확인한다.

\section{5. 강건성 검정}

\section{1 포트폴리오 구성기간의 변경}

<표 2>에서는 식 (2)에 따라 과거 12 개월 $(J=12)$ 의 주식데이터를 기반으로 한 계속적 과잉반응 (CO)을 사용한다. 본 절에서는 과거 포트폴리오 구성기간을 변경하여 $\mathrm{CO}$ 전략의 수익성의 변화를 확인한다. 기존의 과거 12 개월의 주식데이터를 사용한 것과 달리 본 절에서는 과거 6 개월, 9 개월, 18 개월, 그리고 24 개월 동안의 주식데이터를 기반으로 $\mathrm{CO}$ 를 계산한다.

<표 10>은 과거 $J$ 개월의 월별수익률과 월별거래대금으로 도출된 $\mathrm{CO}$ 변수를 기준으로 포트폴리오를 구성한 결과다. 각 열은 보유기간 $(\mathrm{K})$ 이 6개월, 9 개월, 그리고 12 개월인 경우 포트폴리오 수익률을 나타낸다. <표 10>의 패널 A는 포트폴리오 구성기간이 식 (2)에서 제시한 과거 12 개월보다 짧은 경우의 결과다. $J=6$ 일 때 보유기간에 따른 무비용 포트폴리오의 수익률은 $0.593 \%, 0.739 \%, 0.570 \%$ 로 유의한 양의 수익률이다. 포트폴리오 수익률은 $J=12$ 일 때에 비하여 낮지만 통계적으로 유의한 양의 수익률을 가진다. 위험조정 수익률의 경우 <표 $2>$ 와 유사하게 위험요인이 추가됨에 따라 포트폴리오 전략의 수익률이 감소한다. 하지만, CAPM, FF3에 의해 위험을 조정한 수익률은 보유기간이 6 개월일 경우를 제외하고 모두 유의한 양의 값이다. $J=9$ 일 경우 포트폴리오 수익률의 차이는 $0.761 \%, 0.788 \%, 0.597 \%$ 로 유의한 양의 값이다. $J=9$ 일 때 수익률은 $J=6$ 일 경우의 결과보다 대체적으로 높고 $J=12$ 일 때 수익률보다 낮다. 이러한 결과는 위험조정 수익률에서도 유사한 형태로 유지된다. 패널 $\mathrm{B}$ 는 과거 12 개월보다 긴 기간의 주식데이터를 기반으로 $\mathrm{CO}$ 변수를 구성한 결과다. $J=18$ 일 경우 보유기간에 따른 무비용 포트폴리오는 $0.781 \%, 0.752 \%, 0.594 \%$ 이며 통계적으로 유의한 양의 값이다. $J=24$ 일 경우에는 보유기간에 따라 각각 $0.787 \%, 0.753 \%, 0.581 \%$ 의 수익률을 가진다. 포트폴리오 구성기간이 18 개월, 24 개월일 때 위험조정 수익률은 유의한 양의 값을 가진다. 패널 $\mathrm{B}$ 는 과거 12 개월의 주식데이터를 기반으로 $\mathrm{CO}$ 를 도출한 포트폴리오 결과인 <표 $2>$ 와 유사한 값을 가진다. 하지만, <표 2>의 결과에 비하여 대체적으로 낮은 수익률을 가진다는 점에서, 과거 12 개월의 주식데이터를 기준으로 계속적 과잉반응을 정의하였을 경우 $\mathrm{CO}$ 가 가장 높은 포트폴리오와 가장 낮은 포트폴리오의 수익률이 극단적으로 차이가 난다는 사실을 재확인한다. 
〈표 10〉 포트폴리오 구성기간에 따른 CO 포트폴리오의 수익률

이 표는 식 (2)로 도출된 $\mathrm{CO}$ 변수의 포트폴리오 구성기간을 변경한 결과다. 패널 $\mathrm{A}$ 는 포트폴리오 구성기간이 12 개월보다 짧은 경우 $(J<12) \mathrm{CO}$ 포트폴리오의 수익률이고, 패널 $\mathrm{B}$ 는 포트폴리오 구성기간이 12 개월보다 긴 경우 $(J>12) \mathrm{CO}$ 포트폴리오의 수익률이다. CAPM은 시장요인으로 위험을 조정한 수익률이고, $\mathrm{FF} 3$ 은 Fama and French(1993)의 3요인으로 위험을 조정한 수익률이다. 보유기간은 각각 6 개월 $(K=6)$, 9 개월 $(K=9), 12$ 개월 $(K=12)$ 이다. 수익률은 퍼센트 단위다. 표본은 2000년 1월부터 2020년 6월까지 유가증권시장과 코스닥시장에 상장된 보통주 중에서 주당 가격이 500 원보다 큰 주식이다. ${ }^{* * *},{ }^{* *},{ }^{*}$ 는 각각 $1 \%, 5 \%, 10 \%$ 유의수준에서 유의함을 표시한다. 괄호 안의 숫자는 Newey and West(1987) t-통계량이다.

패널 $\mathrm{A}$ : 포트폴리오 구성기간이 12 개월보다 짧은 경우

\begin{tabular}{|c|c|c|c|c|c|c|c|}
\hline \multirow{2}{*}{\multicolumn{2}{|c|}{ CO 포트폴리오 }} & \multicolumn{3}{|c|}{$J=6$} & \multicolumn{3}{|c|}{$\mathrm{J}=9$} \\
\hline & & $\mathrm{K}=6$ & $K=9$ & $K=12$ & $K=6$ & $K=9$ & $\mathrm{~K}=12$ \\
\hline \multirow[t]{9}{*}{ Low } & 1 & 0.621 & 0.553 & 0.594 & 0.544 & 0.527 & 0.591 \\
\hline & 2 & 0.815 & 0.762 & 0.744 & 0.694 & 0.682 & 0.729 \\
\hline & 3 & 0.986 & 0.886 & 0.870 & 0.879 & 0.841 & 0.873 \\
\hline & 4 & 1.033 & 0.934 & 0.935 & 0.946 & 0.900 & 0.929 \\
\hline & 5 & 1.072 & 1.022 & 1.005 & 1.095 & 1.017 & 1.010 \\
\hline & 6 & 1.066 & 1.068 & 1.055 & 1.077 & 1.032 & 1.050 \\
\hline & 7 & 1.150 & 1.094 & 1.049 & 1.195 & 1.135 & 1.125 \\
\hline & 8 & 1.224 & 1.168 & 1.115 & 1.234 & 1.210 & 1.170 \\
\hline & 9 & 1.262 & 1.275 & 1.208 & 1.360 & 1.282 & 1.210 \\
\hline \multicolumn{2}{|c|}{ High 10} & 1.214 & 1.293 & 1.164 & 1.305 & 1.315 & 1.189 \\
\hline \multirow{2}{*}{\multicolumn{2}{|c|}{ High-Low }} & $0.593^{* * *}$ & $0.739^{* * *}$ & $0.570^{* * * *}$ & $0.761^{* * *}$ & $0.788^{* * *}$ & $0.597^{* * *}$ \\
\hline & & (3.803) & $(5.210)$ & $(4.390)$ & $(4.402)$ & $(5.031)$ & (4.113) \\
\hline \multirow{3}{*}{\multicolumn{2}{|c|}{$\begin{array}{l}\mathrm{CAPM} \\
\text { 위험조정 수익률 } \\
\mathrm{FF3}\end{array}$}} & $0.621^{* * *}$ & $0.763^{* * *}$ & $0.589^{* * *}$ & $0.765^{* * *}$ & $0.801^{* * *}$ & $0.616^{* * *}$ \\
\hline & & $(9.876)$ & (11.831) & $(8.856)$ & (11.110) & (11.412) & $(8.441)$ \\
\hline & & 0.089 & $0.357^{* * *}$ & $0.260^{* * * *}$ & $0.152^{*}$ & $0.327^{* * *}$ & $0.231^{* * *}$ \\
\hline \multicolumn{2}{|c|}{ 위험조정 수익률 } & $(1.124)$ & $(6.082)$ & $(4.692)$ & $(1.755)$ & $(4.570)$ & (3.339) \\
\hline \multicolumn{8}{|c|}{ 패널 B: 포트폴리오 구성기간이 12 개월보다 긴 경우 } \\
\hline \multirow{2}{*}{\multicolumn{2}{|c|}{$\mathrm{CO}$ 포트폴리오 }} & \multicolumn{3}{|c|}{$\mathrm{J}=18$} & \multicolumn{3}{|c|}{$\mathrm{J}=24$} \\
\hline & & $K=6$ & $K=9$ & $\mathrm{~K}=12$ & $K=6$ & $\mathrm{~K}=9$ & $\mathrm{~K}=12$ \\
\hline \multirow[t]{9}{*}{ Low } & 1 & 0.537 & 0.487 & 0.515 & 0.424 & 0.432 & 0.507 \\
\hline & 2 & 0.736 & 0.746 & 0.782 & 0.854 & 0.939 & 0.954 \\
\hline & 3 & 0.955 & 0.884 & 0.897 & 0.901 & 0.957 & 1.015 \\
\hline & 4 & 1.054 & 1.041 & 1.052 & 1.040 & 1.064 & 1.093 \\
\hline & 5 & 1.061 & 1.059 & 1.075 & 1.157 & 1.165 & 1.154 \\
\hline & 6 & 1.162 & 1.130 & 1.126 & 1.226 & 1.222 & 1.238 \\
\hline & 7 & 1.249 & 1.165 & 1.176 & 1.244 & 1.238 & 1.226 \\
\hline & 8 & 1.237 & 1.180 & 1.148 & 1.149 & 1.149 & 1.162 \\
\hline & 9 & 1.275 & 1.190 & 1.129 & 1.257 & 1.242 & 1.223 \\
\hline High & & 1.318 & 1.239 & 1.109 & 1.211 & 1.185 & 1.088 \\
\hline \multirow{2}{*}{\multicolumn{2}{|c|}{ High-Low }} & $0.781^{* * *}$ & $0.752^{* * *}$ & $0.594^{* * * *}$ & $0.787^{* * *}$ & $0.753^{* * *}$ & $0.581^{* * *}$ \\
\hline & & $(3.811)$ & $(3.850)$ & $(3.177)$ & $(3.350)$ & $(3.446)$ & $(2.810)$ \\
\hline \multicolumn{2}{|c|}{ CAPM } & $0.752^{* * * *}$ & $0.748^{* * *}$ & $0.598^{* * * *}$ & $0.802^{* * * *}$ & $0.793^{* * *}$ & $0.621^{* * *}$ \\
\hline \multirow{2}{*}{\multicolumn{2}{|c|}{$\begin{array}{l}\text { 위험조정 수익률 } \\
\text { FF3 }\end{array}$}} & $(8.514)$ & $(8.160)$ & $(6.462)$ & $(6.981)$ & $(7.255)$ & $(6.071)$ \\
\hline & & $0.252^{* *}$ & $0.393^{* * *}$ & $0.321^{* * *}$ & $0.374^{* * *}$ & $0.474^{* * *}$ & $0.390^{* * *}$ \\
\hline \multicolumn{2}{|c|}{$\begin{array}{l}\mathrm{FF} 3 \\
\text { 위험조정 수익륙 }\end{array}$} & $(2.478)$ & $(4.489)$ & $(3.996)$ & $(3.670)$ & $(5.395)$ & $(5.049)$ \\
\hline
\end{tabular}


Empirical Investigation of the Relationship between Continuing Overreaction and Stock Returns

요약하면, 본 연구에서는 국내 주식시장의 계속적 과잉반응을 분석하기 위해 과거 12 개월의 월별거래대금과 월별수익률을 통해 $\mathrm{CO}$ 변수를 도출한다. 그 결과 <표 $2>$ 에 따라 $\mathrm{CO}$ 전략은 유의한 양의 수익률을 가진다. 본 절에서는 위의 결과의 강건함을 확인하기 위하여 포트폴리오 구성기간을 변경한다. 과거 6 개월, 9 개월, 18 개월, 그리고 24 개월을 기반으로 계속적 과잉반응을 도출한 결과, 모든 기간에서 $\mathrm{CO}$ 를 기준으로 한 무비용 포트폴리오는 유의한 양의 수익률을 가진다. 따라서 투자자의 계속적 과잉반응은 포트폴리오 구성기간에 무관하게 주식수익률과 유의한 양의 관계를 가진다는 사실을 재확인한다.

\section{2 시장상태와 시장동태에 따른 결과}

본 절에서는 시장상태(market state)와 시장동태(market dynamics)에 따른 CO전략을 재확인 한다. Cooper et al.(2004)에 따르면 단기 모멘텀 수익률은 시장상태에 따라 결정된다. 이들은 과거 3년 시장수익률이 음수가 아닐 경우 상승시장(UP), 음수일 경우 하락시장 $(\mathrm{DOWN})$ 으로 정의한다. 기존의 연구에 의하면, 미국시장에서 모멘텀 현상은 전적으로 상승시장을 따른다. Asem and Tian(2010)은 시장동태에 의해 미국의 하락시장에서 모멘텀 수익률이 발생하지 않는다고 주장한다. 위의 연구결과에 따르면 시장이 변화할 때와 동일한 시장상태를 유지할 때 모멘텀 전략의 수익률을 차이를 가진다. Cheema and Nartea(2017)은 위의 두 연구를 기반으로 중국 주식시장을 분석한 결과, 중국 주식시장에서는 하락시장에서 모멘텀 수익률이 발생함을 확인한다. Du et al.(2009)은 대만 주식시장에서 하락시장이 자주 발생하며 하락시장에서의 모멘텀 수익률은 미국의 경우보다 더 높은 음의 값을 가진다고 나타낸다. 또한, 신흥시장에서의 모멘텀 전략의 부재는 문화적 차이보다는 국가의존성에 의한 것이라고 주장한다. Huang(2006)에 따르면 17 개국을 대상으로 시장상태에 따른 모멘텀 전략을 분석한 결과, 대부분의 국가에서 상승시장일 경우 모멘텀 수익률을 가진다.

본 절에서는 기존의 연구를 기반으로 시장상태와 시장동태에 따른 $\mathrm{CO}$ 전략의 수익성을 확인한다. <표 $11>$ 의 패널 $\mathrm{A}$ 는 시장상태에 따른 $\mathrm{CO}$ 전략을 나타내고, 패널 $\mathrm{B}$ 는 시장동태에 따른 $\mathrm{CO}$ 전략을 나타낸다. 먼저, 시장상태에 따른 계속적 과잉반응을 확인하기 위하여 Cooper et al.(2004)에 따라 시장을 상승기와 하락기로 나눈다. 만약 과거 12 개월의 시장수익률이 음수가 아니면 상승시장(UP), 음수면 하락시장 $(\mathrm{DOWN})$ 으로 정의한다. 246개월의 표본기간 중 177 개월은 상승시장으로 분류되고, 57 개월은 하락시장으로 분류된다. <표 $11>$ 의 패널 $\mathrm{A}$ 에 따르면 상승시장과 하락시장에서 계속적 과잉반응과 주식수익률 간에는 유의한 양의 관계가 있다. 상승시장에서 $\mathrm{CO}$ 가 높은 포트폴리오를 매입하고 낮은 포트폴리오를 매도하는 전략은 $0.537 \%$ 의 유의한 양의 수익률을 가진다. 하락시장의 경우 $0.844 \%$ 의 수익률을 가지며, 통계적으로 유의한 값이다. UP-DOWN은 상승시장의 수익률과 하락시장의 수익률 차이다. 상승시장과 하락시장 간의 차이는 $-0.294 \%$ 이고 $\mathrm{t}$-통계량은 -1.481 로 유의하지 않다. 이는 상승시장과 하락시장 간의 차이가 0 과 같다는 것을 의미한다. 따라서 $\mathrm{CO}$ 전략은 상승시장과 하락시장에 대한 영향을 받지 않고, 시장상태에 상관없이 유의한 양의 수익률을 가진다.

다음으로, 시장동태에 따른 계속적 과잉반응의 존재여부를 확인한다. 우리는 Asem and $\operatorname{Tian}(2010)$ 에 따라 과거 12 개월의 시장수익률과 동시간대 시장수익률을 이용하여 시장동태를 
한국증권학회지 제 50 권 1호 (2021)

정의한다. 과거 시장수익률은 $t-12$ 월부터 $t-2$ 월까지의 시장수익률을 의미하고, 동시간대 시장수익률은 $t$ 월의 시장수익률이다. 시장동태는 다음과 같이 분류된다. 과거 시장상태가 상승시장일 때, 동시간대 시장수익률이 양의 값이면 $\mathrm{U} / \mathrm{U}$ 이고 음의 값이면 $\mathrm{U} / \mathrm{D}$ 로 정의한다. 과거 시장상태가 하락시장일 때, 동시간대 시장수익률이 양의 값이면 $\mathrm{D} / \mathrm{U}$ 이고 음의 값이면 $\mathrm{D} / \mathrm{D}$ 로 정의한다. <표 $11>$ 의 패널 $\mathrm{B}$ 에 따르면, 과거시장이 상승시장일 경우 $(\mathrm{U} / \mathrm{U}, \mathrm{U} / \mathrm{D})$ 수익률은 $0.848 \%, 0.792 \%$ 이며, 상승시장이 유지될 경우 $(\mathrm{U} / \mathrm{U})$ 에 더 높은 수익률과 $\mathrm{t}$-통계량을 가진다. 반면, 과거시장이 하락시장일 경우 $(\mathrm{D} / \mathrm{U}, \mathrm{D} / \mathrm{D})$ 수익률은 $0.801 \%, 0.767 \%$ 이며, 동시간대 시장에

\section{〈표 11〉시장상태와 시장동태에 따른 $\mathrm{CO}$ 전략}

이 표는 시장상태와 시장동태에 따른 $\mathrm{CO}$ 전략의 수익률이다. 과거 12 개월 시장수익률이 음수가 아닌 경우를 상승시장 $(\mathrm{UP})$, 음수인 경우를 하락시장 $(\mathrm{DOWN})$ 으로 정의한다. $\mathrm{UP}-\mathrm{DOWN}$ 은 상승시장과 하락시장 간의 수익률 차이다. 시장동태는 과거 12 개월 시장수익률과 동시간대 시장수익률로 구성된다. 과거 시장상태가 상승시장일 때, 동시간대 시장수익률이 양의 값이면 U/U이고 음의 값이면 U/D로 정의된다. 과거 시장상태가 하락시장일 때, 동시간대 시장수익률이 양의 값이면 $\mathrm{D} / \mathrm{U}$ 이고 음의 값이면 $\mathrm{D} / \mathrm{D}$ 로 정의된다. 보유기간은 6 개월 $(K=6)$ 이고, 수익률은 퍼센트 단위다. 표본은 2000년 1월부터 2020년 6월까지 유가증권 시장과 코스닥시장에 상장된 보통주 중에서 주당 가격이 500 원보다 큰 주식이다. ${ }^{* * *},{ }^{* *},{ }^{*}$ 는 각각 $1 \%$, $5 \%, 10 \%$ 유의수준에서 유의함을 표시한다. 괄호 안의 숫자는 Newey and West(1987) t-통계량이다.

패널 $\mathrm{A}$ : 상승시장과 하락시장에 따른 $\mathrm{CO}$ 전략

\begin{tabular}{cccc}
\hline CO 포트폴리오 & UP & DOWN & UP-DOWN \\
\hline Low 1 & 0.287 & 1.121 & \\
2 & 0.453 & 1.427 & \\
3 & 0.628 & 1.779 & \\
4 & 0.688 & 1.991 & -0.294 \\
High 5 & 0.824 & 1.964 & $(-1.481)$ \\
High-Low & $0.537^{* * *}$ & $0.844^{* * *}$ & -0.008 \\
& $(4.004)^{* * *}$ & $(3.681)$ & $(-0.056)$ \\
CAPM & $0.552^{* * *}$ & $0.561^{* * *}$ & 0.184 \\
위험조정 수익률 & $(10.827)$ & $(3.843)$ & $(1.451)$ \\
FF3 & $0.166^{* *}$ & -0.008 & \\
위험조정 수익률 & $(2.442)$ & $(-0.058)$ & \\
\hline
\end{tabular}

패널 $\mathrm{B}$ : 시장동태에 따른 $\mathrm{CO}$ 전략

\begin{tabular}{ccccc}
\hline CO 포트폴리오 & $\mathrm{U} / \mathrm{U}$ & $\mathrm{U} / \mathrm{D}$ & $\mathrm{D} / \mathrm{U}$ & $\mathrm{D} / \mathrm{D}$ \\
\hline Low 1 & 0.269 & 0.505 & 0.598 & 0.590 \\
2 & 0.588 & 0.755 & 0.839 & 0.850 \\
3 & 0.905 & 1.027 & 1.137 & 1.106 \\
4 & 0.952 & 1.110 & 1.258 & 1.230 \\
High 5 & 1.117 & 1.297 & 1.399 & 1.358 \\
High-Low & $0.848^{* * *}$ & $0.792^{* * *}$ & $0.801^{* * *}$ & $0.767^{* * *}$ \\
& $(4.774)$ & $(4.479)$ & $(5.002)$ & $(4.785)$ \\
CAPM & $0.874^{* * *}$ & $0.807^{* * *}$ & $0.751^{* * *}$ & $0.708^{* * *}$ \\
위험조정 수익률 & $(10.908)$ & $(10.092)$ & $(9.957)$ & $(9.973)$ \\
FF3 & $0.289^{* * *}$ & $0.259^{* * *}$ & $0.269^{* * *}$ & $0.197^{* * *}$ \\
위험조정 수익률 & $(3.942)$ & $(3.104)$ & $(3.577)$ & $(2.708)$ \\
\hline
\end{tabular}


Empirical Investigation of the Relationship between Continuing Overreaction and Stock Returns

상승시장인 경우 $(\mathrm{D} / \mathrm{U})$ 의 수익률이 더 높다. 따라서 과거시장이 상승시장 또는 하락시장일 경우, 동시간대 시장이 상승시장일 때 상대적으로 더 높은 수익률을 가진다.

본 절에서는 시장상태와 시장동태에 따른 $\mathrm{CO}$ 전략의 수익성을 재점검한다. 시장상태에 따라 분석한 결과, 상승시장과 하락시장에서 계속적 과잉반응과 주식수익률은 유의한 양의 관계에 있다. 시장동태에 따라 분석한 결과, 모든 경우에서 $\mathrm{CO}$ 전략은 유의한 양의 수익률을 가진다. 특히, 상승시장이 유지될 경우 가장 높은 수익률을 가지며 하락시장이 유지될 경우 가장 낮은 수익률을 가진다. 종합하면, 국내 주식시장에서 $\mathrm{CO}$ 전략은 시장상태와 시장동태에 상관없이 모두 유의한 양의 수익성을 가진다는 것을 재확인한다.

\section{6. 결론}

최근의 많은 연구들은 투자자의 과신이 전통적 가격결정 모형으로 설명할 수 없는 주식시장의 현상들을 설명한다고 주장한다. 특히, Daniel et al.(1998)은 투자자의 과신과 편향된 자기귀인을 기반으로 주식시장의 과소반응과 과잉반응을 설명한다. 이 후 다수의 실증연구가 위의 모형을 뒷받침하는 증거를 제시한다. Byun et al.(2016)은 미국 주식시장을 표본으로 하여 투자자의 과신과 편향된 자기귀인으로 인한 계속적 과잉반응이 주식수익률을 예측한다는 모형을 제시한다. 가중치가 부여된 부호화된 거래량을 이용한 $\mathrm{CO}$ 변수를 정의하고, $\mathrm{CO}$ 를 기준으로 포트폴리오 분석을 통해 $\mathrm{CO}$ 는 주식수익률과 유의한 양의 관계에 있음을 확인한다.

본 연구는 국내 주식시장을 표본으로 Byun et al.(2016)에 따라 투자자의 계속적 과잉반응과 주식수익률간의 관계를 분석한다. $\mathrm{CO}$ 를 기준으로 10 분위수 포트폴리오를 구성하여 $\mathrm{CO}$ 가 가장 높은 포트폴리오에 속한 주식을 매입하고, $\mathrm{CO}$ 가 가장 낮은 포트폴리오에 속한 주식을 매도하는 전략은 비정상적인 양의 수익률을 창출한다. 우리는 계속적 과잉반응의 전략과 모멘텀간의 관계를 분석한 선행연구의 한계를 극복하기 위하여 여러 가지 통제변수를 이용한 다변량 포트폴리오 분석을 사용한다. 다변량 포트폴리오 분석을 이용하여 주식수익률에 대한 계속적 과잉반응의 예측력을 확인한다.

먼저, Daniel et al.(1998)의 모델은 모멘텀 현상을 설명하는 선도적인 행동요인으로 계속적 과잉반응을 제시한다. $\mathrm{CO}$ 변수가 과거수익률에 비하여 미래수익률을 잘 예측한다면, 이는 위의 모델을 지지하는 증거가 된다. 우리는 모멘텀전략의 수익률을 조정한 $\mathrm{CO}$ 전략의 수익률이 여전히 유의한 양의 수익률을 가지는 것을 확인한다. 반면, 모멘텀 전략의 경우 $\mathrm{CO}$ 를 제어한 후에 단조로운 증가패턴이 사라진다. $\mathrm{CO}$ 전략의 포트폴리오 수익률에서 더 높은 샤프비율과 유의한 단조로운 증가패턴을 보여준다.

우리는 선행연구에 의하여 주식수익률에 유의한 영향을 미친다고 나타난 기업특성 요인을 통제하여 기존 연구의 한계를 극복한다. 기업특성 요인인 기업규모, 장부가치 대 시장가치, 과거수익률, 단기수익률반전, 유동성, 고유변동성, 거래량회전율을 통제한 후 여전히 CO전략이 유의한 양의 수익률을 가짐을 확인한다. 그 결과, $\mathrm{CO}$ 전략의 수익성은 기업특성 요인에 기인한 것이 아니라는 것을 나타낸다. 더 나아가, 수익률 지속성과 정보의 불연속성을 제어한 경우에도 $\mathrm{CO}$ 포트폴리오 수익률은 단조로운 패턴을 유지하고, $\mathrm{CO}$ 전략은 유의한 양의 수익률을 가진다. 
한국증권학회지 제 50 권 1호 (2021)

또한, Grinblatt and $\operatorname{Han}(2005)$ 에 따라 모멘텀을 설명하는 핵심요인인 미실현 자본이익이 $\mathrm{CO}$ 전략에 미치는 영향을 분석한다. 그 결과, 국내 주식시장에서 양의(음의) 미실현 자본이익을 가진 주식은 투자자들에게 저평가(고평가)되어 높은(낮은) 주식수익률을 가지는 현상이 나타남 에도 불구하고, 미실현 자본이익을 통제한 후 $\mathrm{CO}$ 전략은 여전히 유의한 양의 수익률을 가진다. 따라서 $\mathrm{CO}$ 변수가 미래수익률을 예측할 수 있으며, 과거 수익률보다 미래수익률에 대한 예측성이 높다는 사실을 확인한다.

추가적으로, $\mathrm{CAPM}$ 으로 도출된 잔여수익률을 이용하여 잔여 계속적 과잉반응 측정치를 정의한다. 기존의 선행연구에 따르면 잔여모멘텀은 모멘텀 전략보다 더 높고 일관성 있는 성과를 가진다. 우리는 모멘텀과 유사한 결과를 가지는 계속적 과잉반응에 대한 분석을 진행한다. 그 결과, 잔여 계속적 과잉반응은 기존의 계속적 과잉반응과 유사하게 주식수익률에 대한 양의 예측력을 가진다. 하지만, 무비용 포트폴리오 전략과 누적수익률의 경우에서 기존의 계속적 과잉반응에 의한 수익률이 더 높은 값을 가진다. $\mathrm{RCO}$ 전략의 잔여모멘텀 조정수익률은 증가하는 패턴을 가지는 반면, 잔여모멘텀 포트폴리오의 $\mathrm{RCO}$ 조정수익률은 통계적으로 유의하지 않다. 다시 말해, 국내 주식시장에서 잔여모멘텀의 영향은 $\mathrm{RCO}$ 에 의하여 설명된다. 따라서 잔여 수익률로 도출된 잔여 계속적 과잉반응보다 주식수익률을 기반으로 도출된 계속적 과잉반응이 미래수익률과 더 강한 양의 관계를 가짐을 확인한다.

강건성 검정에서는 포트폴리오 구성기간을 변경한 결과와 시장상태, 시장동태에 따른 결과를 나타낸다. 포트폴리오 구성기간을 6 개월, 9 개월, 18 개월, 24 개월로 변경한 결과, $\mathrm{CO}$ 전략은 여전히 유의한 양의 수익률을 가진다. 그럼에도 불구하고, 과거 12 개월 수익률로 포트폴리오를 구성하였을 경우 포트폴리오의 수익률이 가장 높은 값을 가지므로 과거 12 개월 수익률로 계속적 과잉반응을 추정하는 것을 지지한다. 추가적으로 시장상태와 시장동태에 따른 $\mathrm{CO}$ 전략을 분석한다. 기존의 연구에 의하면 모멘텀 전략은 상승시장에서 더욱 뚜렷하게 나타난다. 반면, $\mathrm{CO}$ 전략은 상승시장과 하락시장 모두 유의한 양의 수익률을 가진다. 이와 유사하게, 시장동태에 따른 결과도 모두 유의한 양의 값을 가진다. 본 연구의 결과는 과신과 편향된 자기귀인으로 인한 투자자의 계속적 과잉반응이 주식수익률 예측성을 가진다는 Byun et al.(2016)의 주장을 지지한다.

본 연구는 잘 알려진 두 가지의 심리적 편향인 투자자의 과신과 편향된 자기귀인을 기반으로 주식시장의 과소반응과 과잉반응 현상을 설명한다. 거래량을 기반으로 계속적 과잉반응을 정의하고 국내 주식시장을 분석했다는 기여를 가지며, 관련분야의 발전에도 의미 있는 시사점을 준다. 또한, 국내 주식시장에서 뚜렷한 모멘텀현상이 발생하지 않는다는 기존의 선행연구를 기반으로 모멘텀현상의 핵심변수로 제시된 계속적 과잉반응의 유의한 영향을 제시한다. 특히, 기존의 모멘텀에 비하여 더 높은 수익률과 일관성을 가진다는 잔여모멘텀의 개념을 도입하여 잔여 계속적 과잉반응을 제시한다. 잔여수익률을 이용한 계속적 과잉반응은 기존의 계속적 과잉반응에 비하여 주식수익률에 낮은 영향을 주지만, 국내 주식시장에서 유의한 영향을 미침을 확인한다. 시간이 지남에 따라 국내 주식시장에서 투자자의 행태적 요인이 주식시장과 주식가격에 미치는 영향에 대한 연구가 증가하고 있다. 본 연구는 투자자의 심리적 편향이 주식시장에 미치는 영향과 심리적 편향으로 인해 발생하는 현상을 설명하는데 있어 관련분야에 의미 있는 시사점을 준다. 
Empirical Investigation of the Relationship between Continuing Overreaction and Stock Returns

\section{References}

Adebambo, B. N., and X. Yan, 2016, Momentum, Reversals, and Fund Manager Overconfidence, Financial Management, Vol. 45 (3), pp. 609-39.

Alwathainani, A. M., 2009, Consistency of Firms' Past Financial Performance Measures and Future Returns, The British Accounting Review, Vol. 41 (3), pp. 184-96.

Amihud, Y., 2002, Illiquidity and Stock Returns: Cross-Section and Time-Series Effects, Journal of Financial Markets, Vol. 5 (1), pp. 31-56.

An, L., H. Wang, J. Wang, and J. Yu, 2019, Lottery-Related Anomalies: The Role of Reference-Dependent Preferences, Management Science, Vol. 66 (1), pp. 473-501.

Asem, E., and G. Y. Tian, 2010, Market dynamics and momentum profits, Journal of Financial and Quantitative Analysis, Vol. 45 (6), pp. 1549-1562.

Bali, T. G., N. Cakici, and R. Whitelaw, 2011, Maxing out: Stocks as Lotteries and the Cross-Section of Expected Returns, Journal of Financial Economics, Vol. 99 (2), pp. $427-46$.

Barillas, F., and J. Shanken, 2018, Comparing asset pricing models, The Journal of Finance, Vol. 73 (2), pp. 715-754.

Benos, A. V. 1998, Aggressiveness and Survival of Overconfident Traders, Journal of Financial Markets, Vol. 1 (3-4): 353-383.

Blitz, D., M. X. Hanauer, and M. Vidojevic, 2020, The Idiosyncratic Momentum Anomaly, International Review of Economics \& Finance, Vol. 69, pp. 932-957.

Blitz, D., J. Huij, and M. Martens, 2011, Residual Momentum, Journal of Empirical Finance, Vol. 18 (3), pp. 506-521.

Byun, S. J., S. S. Lim, and S. H. Yun, 2016, Continuing Overreaction and Stock Return Predictability, Journal of Financial and Quantitative Analysis, Vol. 51 (6), pp. 2015-2046.

Cheema, M, A., and G. V. Nartea, 2017, Momentum Returns, Market States, and Market Dynamics: Is China Different?, International Review of Economics \& Finance, Vol. 50, pp. 85-97.

Chen, G., K. A. Kim, J. R. Nofsinger, and O. M. Rui, 2007, Trading Performance, Disposition Effect, Overconfidence, Representativeness Bias, and Experience of Emerging Market Investors, Journal of Behavioral Decision Making, Vol. 20 (4), pp. 425-451.

Chuang, W. I., B. S. Lee, 2006, An Empirical Evaluation of the Overconfidence Hypothesis, Journal of Banking and Finance, Vol. 30 (9), pp. 2489-2515.

Chui, A. C. W., S. Titman, and K. C. J. Wei, 2010, Individualism and Momentum around the World, The Journal of Finance, Vol. 65 (1), pp. 361-92.

Cooper, M. J., R. C. Gutierrez, and A. Hameed, 2004, Market States and Momentum, The 
한국증권학회지 제 50 권 1호 (2021)

Journal of Finance, Vol. 59 (3), pp. 1345-1365.

Da, Z., U. G. Gurun, and M. Warachka, 2014. Frog in the Pan: Continuous Information and Momentum, The Review of Financial Studies, Vol. 27 (7), pp. 2171-2218.

Daniel, K., D. Hirshleifer, and A. Subrahmanyam, 1998, Investor Psychology and Security Market Under-and Overreactions, The Journal of Finance, Vol. 53 (6), pp. 1839-1885.

Du, D., Z. Huang, and B. S. Liao, 2009, Why Is There No Momentum in the Taiwan Stock

Market?, Journal of Economics and Business, Vol. 61 (2), pp. 140-152.

Eom, Y., 2013, Momentum Profits and Firm Size, Korean Journal of Financial Studies, Vol. 41 (3), pp. 901-927.

Fama, E. F., and K. R. French, 1992, The Cross-section of Expected Stock Returns, The Journal of Finance, Vol. 47 (2), pp. 427-465.

Fama, E. F., and K. R. French, 1993, Common Risk Factors in the Returns on Stocks and Bonds, Journal of Financial Economics, Vol. 33 (1), pp. 3-56.

Fama, E. F., and K. R. French, 2015, A Five-Factor Asset Pricing Model, Journal of Financial Economics, Vol. 116 (1), pp. 1-22.

Fama, E. F., and K. R. French, 2017, International Tests of a Five-Factor Asset Pricing Model, Journal of Financial Economics, Vol. 123 (3), pp. 441-463.

Fama, E. F., and J. D. MacBeth, 1973, Risk, return and equilibrium: Empirical tests, Journal of Political Economy, Vol. 81 (3), pp. 607-636.

Gervais, S., and T. Odean, 2001, Learning to Be Overconfident, The Review of Financial Studies, Vol. 14 (1), pp. 1-27.

Glaser, M., and M. Weber, 2009, Which Past Returns Affect Trading Volume?, Journal of Financial Markets, Vol. 12 (1), pp. 1-31.

Griffin, J. M., J. Xiuqing, and J. S. Martin, 2003, Momentum Investing and Business Cycle Risk: Evidence from Pole to Pole, The Journal of Finance, Vol. 58 (6), pp. 2515-2547.

Grinblatt, M., and B. Han, 2005, Prospect Theory, Mental Accounting, and Momentum, Journal of Financial Economics, Vol. 78 (2), pp. 311-339.

Grinblatt, M., and M. Keloharju, 2009, Sensation Seeking, Overconfidence, and Trading Activity, The Journal of Finance, Vol. 64 (2), pp. 549-578.

Grinblatt, M., and T. J. Moskowitz, 2004, Predicting Stock Price Movements from Past Returns: The Role of Consistency and Tax-Loss Selling, Journal of Financial Economics, Vol. 71 (3), pp. 541-579.

Gutierrez, J., and C. Prinsky, 2007, Momentum, Reversal, and the Trading Behaviors of Institutions, Journal of Financial Markets, Vol. 10 (1), pp. 48-75.

Huang, D., 2006, Market States and International Momentum Strategies, The Quarterly Review of Economics and Finance, Vol. 46 (3), pp. 437-446. 
Empirical Investigation of the Relationship between Continuing Overreaction and Stock Returns

Hou, K., W. Xiong, and L. Peng, 2009, A Tale of Two Anomalies: The Implications of Investor Attention for Price and Earnings Momentum, Working paper, Ohio State University and Princeton University, Available at https://papers.ssrn.com/sol3/papers.cfm?abstr act_id=976394.

Jang, J., 2017, Price Momentum Anomaly Revisited : Evidence in the Korean Stock Market, Asian Review of Financial Research, Vol. 30 (3), pp. 317-359.

Jegadeesh, N., 1990, Evidence of Predictable Behavior of Security Returns, The Journal of Finance, Vol. 45 (3), pp. 881-898.

Jegadeesh, N., and S. Titman, 1993, Returns to Buying Winners and Selling Losers: Implications for Stock Market Efficiency, The Journal of Finance, Vol. 48 (1), pp. 65-91.

Kam, H., and Y. Shin, 2011, Performance of Investment Strategies by Using Momentum Effect in Korea Stock Market, Korean Journal of Financial Studies, Vol. 18 (1), pp. 265-278.

Lee, C. M. C., and B. Swaminathan, 2000, Price Momentum and Trading Volume, The Journal of Finance, Vol. 55 (5), pp. 2017-2069.

Lehmann, B. N., 1990, Fads, Martingales, and Market Efficiency, The Quarterly Journal of Economics, Vol. 105 (1), pp. 1-28.

Lin, C., K. C. Ko, Y. L. Chen, and H. H. Chu, 2016, Information Discreteness, Price Limits and Earnings Momentum, Pacific-Basin Finance Journal, Vol. 37, pp. 1-22.

Luo, J., A. Subrahmanyam, and S. Titman, 2021, Momentum and Reversals When Overconfident Investors Underestimate Their Competition, The Review of Financial Studies, Vol. 34 (1), pp. 351-393.

Newey, W. K., and K. D. West, 1987, A Simple, Positive Semi-Definite, Heteroskedasticity and Autocorrelation consistent Covariance Matrix, Econometrica, Vol. 55 (3), pp. 703-708.

Odean, T., 1998, Volume, Volatility, Price, and Profit When All Traders Are above Average, The Journal of Finance, Vol. 53 (6), pp. 1887-1934.

Oh, S., and S. Hahn, 2012, Capital Gains and Volume in Measuring Disposition Effect on Return, Korean Journal of Financial Studies, Vol. 41 (3), pp. 437-461.

Oh, S., and S. Hahn, 2013, Asymmetric Disposition Effect on Expected Return, Korean Journal of Financial Studies, Vol. 42 (5), pp. 813-836.

Rouwenhorst, K. G., 1998, International Momentum Strategies, The Journal of Finance, Vol. 53 (1), pp. 267-284.

Statman, M., S. Thorley, and K. Vorkink, 2006, Investor Overconfidence and Trading Volume, The Review of Financial Studies, Vol. 19 (4), pp. 1531-1565.

Watkins, B. D., 2006, Institutional Ownership and Return Reversals Following Short-term Return Consistency, The Financial Review, Vol. 41 (3), pp. 435-448. 
한국증권학회지 제50권 1호 (2021)

\section{〈부록〉}

〈표 A1〉CO와 모멘텀의 스패닝 검정

이 표는 $\mathrm{CO}$ 와 모멘텀(PRET)의 스패닝 검정 결과다. 모형 1-3은 모멘텀(PRET)을, 모형 4-6은 $\mathrm{CO}$ 를 종속변수로 취하고 다른 4 개 변수를 독립변수로 취한 결과다. alpha는 회귀분석의 절편값이며, Mkt는 시장요인을, $\mathrm{SMB}$ 는 규모요인을, $\mathrm{HML}$ 은 가치요인을 나타낸다. $\mathrm{CO}$ 는 계속적 과잉반응이며, $\mathrm{PRET}$ 는 모멘텀이다. 괄호 안의 숫자는 Newey and West(1987) t-통계량이다. 표본은 2000년 1월부터 2020년 6 월까지 유가증권시장과 코스닥시장에 상장된 보통주 중에서 주당 가격이 500 원보다 큰 주식이다. ${ }^{* * *}$, **, "는 각각 $1 \%, 5 \%, 10 \%$ 유의수준에서 유의함을 표시한다. 괄호 안의 숫자는 Newey and West(1987) $\mathrm{t}$-통계량이다.

\begin{tabular}{|c|c|c|c|c|c|c|c|c|}
\hline & & alpha & Mkt & SMB & HML & $\mathrm{CO}$ & PRET & Adj. $R^{2}$ \\
\hline \multirow[t]{3}{*}{ PRET } & 1 & $\begin{array}{c}0.012^{* * * *} \\
(12.332)\end{array}$ & $\begin{array}{c}0.073^{* * *} \\
(3.282)\end{array}$ & & & & & 0.007 \\
\hline & 2 & $\begin{array}{c}0.013^{* * *} \\
(10.987)\end{array}$ & $\begin{array}{c}0.095^{* * * *} \\
(4.088)\end{array}$ & $\begin{array}{c}0.127^{* * *} \\
(3.418)\end{array}$ & $\begin{array}{r}0.027 \\
(1.212)\end{array}$ & & & 0.007 \\
\hline & 3 & $\begin{array}{c}0.006^{* * *} \\
(8.961)\end{array}$ & $\begin{array}{r}0.004 \\
(0.467)\end{array}$ & $\begin{array}{l}0.096^{* * * *} \\
(4.193)\end{array}$ & $\begin{array}{l}0.058^{* * * *} \\
(3.269)\end{array}$ & $\begin{array}{c}0.963^{* * *} \\
(24.936)\end{array}$ & & 0.493 \\
\hline \multirow[t]{3}{*}{$\mathrm{CO}$} & 4 & $\begin{array}{l}0.005^{* * *} \\
(9.401)\end{array}$ & $\begin{array}{l}0.070^{* * * *} \\
(4.930)\end{array}$ & & & & & 0.012 \\
\hline & 5 & $\begin{array}{c}0.007^{* * *} \\
(10.366)\end{array}$ & $\begin{array}{l}0.089^{* * * *} \\
(4.884)\end{array}$ & $\begin{array}{r}0.033 \\
(1.332)\end{array}$ & $\begin{array}{r}-0.028^{*} \\
(-1.653)\end{array}$ & & & 0.020 \\
\hline & 6 & $\begin{array}{l}0.001^{* * * *} \\
(3.261)\end{array}$ & $\begin{array}{l}0.034^{* * *} \\
(4.237)\end{array}$ & $\begin{array}{r}0.004 \\
(0.319)\end{array}$ & $\begin{array}{l}-0.038^{* * *} \\
(-2.700)\end{array}$ & & $\begin{array}{c}0.500^{* * *} \\
(19.323)\end{array}$ & 0.496 \\
\hline
\end{tabular}

